\title{
Leveraging knowledge of Asian herbal medicine and its active compounds as COVID-19 treatment and prevention
}

\author{
Desy Liana ${ }^{1} \cdot$ Anuchit Phanumartwiwath ${ }^{1}$
}

Received: 23 August 2021 / Accepted: 29 September 2021 / Published online: 8 October 2021

(c) The Japanese Society of Pharmacognosy 2021

\begin{abstract}
The outbreak of COVID-19 disease has led to a search for effective vaccines or drugs. However, insufficient vaccine supplies to meet global demand and no effective approved prescribed drugs for COVID-19 have led some people to consider the use of alternative or complementary medicines, such as traditional herbal medicine. Medicinal plants have various therapeutic properties that depend on the active compounds they contain. Obviously, herbal medicine has had an essential role in treatment and prevention during COVID-19 outbreak, especially in Asian cultures. Hence, we reviewed the uses of herbal medicine in Asian cultures and described the prominent families and species that are sources of antiviral agents against COVID-19 on the basis of case reports, community surveys, and guidelines available in the literature databases. Antiviral efficacy as determined in laboratory testing was assessed, and several promising active compounds with their molecular targets in cell models against SARS-CoV-2 viral infection will be discussed. Our review findings revealed the highly frequent use of Lamiaceae family members, Zingiber officinale, and Glycyrrhiza spp. as medicinal sources for treatment of COVID-19. In addition, several plant bioactive compounds derived from traditional herbal medicine, including andrographolide, panduratin A, baicalein, digoxin, and digitoxin, have shown potent SARS-CoV-2 antiviral activity as compared with some repurposed FDA-approved drugs. These commonly used plants and promising compounds are recommended for further exploration of their safety and efficacy against COVID-19.
\end{abstract}

Anuchit Phanumartwiwath

anuchit.p@chula.ac.th

1 College of Public Health Sciences, Chulalongkorn

University, Pathumwan, Bangkok 10330, Thailand 


\section{Graphic abstract}

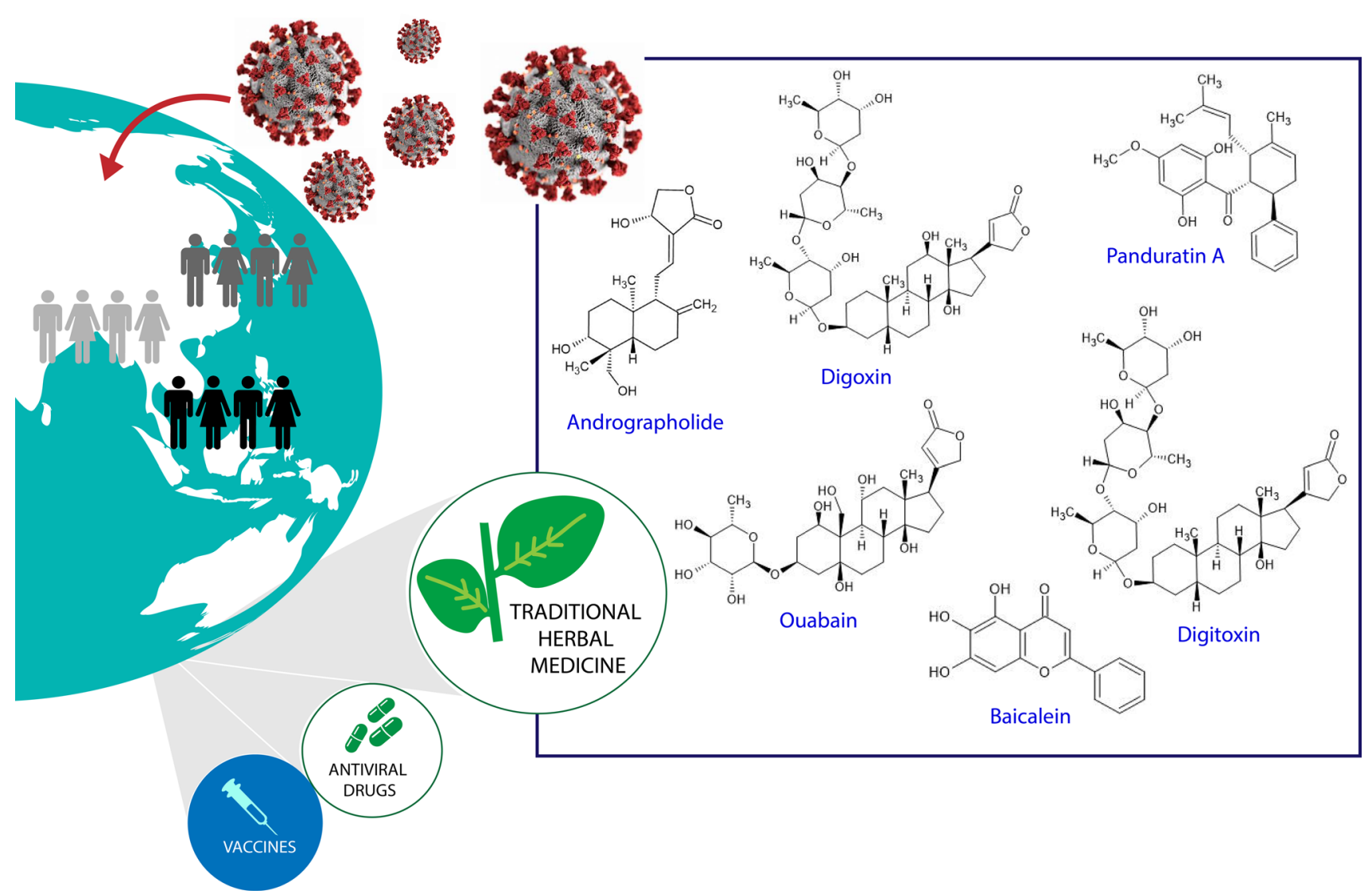

Keywords COVID-19 $\cdot$ Asian $\cdot$ Herbal medicine $\cdot$ Plant bioactive compounds $\cdot$ Treatment $\cdot$ Prevention

\section{Background}

An outbreak of coronavirus 19 (COVID-19) disease caused by the beta-coronavirus, severe acute respiratory syndrome 2 (SARS-CoV-2), was first reported in late December 2019 in Wuhan, China and continued to rapidly spread worldwide. The angiotensin-converting enzyme 2 (ACE2) receptor, which is known to be an entry point of SARS$\mathrm{CoV}-2$, is widely presented on lung alveolar cells but also can be found in other organs' cells, such as the upper esophagus, small intestine, colon, bile, heart, kidney, and bladder; hence, this virus can attack various organs and cause damage $[1,2]$. Penetration by SARS-CoV-2 stimulates the immune response leading to production of various cytokines, which generates a cytokines storm that triggers disease symptoms. Depending on the cytokines produced, COVID-19 symptoms can be mild, moderate, or severe [2]. Severe disease is characterized by progressive lung damage, over-inflammation, pulmonary tissue edema, vascular leakage, coagulation, and endotheliitis (vascular inflammation). The cytokine storms in the most severely affected COVID-19 patients are very destructive and cause endothelial dysfunction, inflammation, and vasodilatation of pulmonary capillaries. Furthermore, this process triggers alveolar disfunction, acute respiratory distress syndrome with hypoxic respiratory, and multiple-organ failure, resulting in death $[3,4]$.

A global effort to develop effective vaccines or therapeutic drugs for COVID-19 disease is urgently needed for combating the pandemic. Hence, several approaches have been adopted, including drug repurposing and vaccine development. In drug repurposing, various existing drugs, such as chloroquine, hydroxychloroquine, ivermectin, camostat mesylate, lopinavir, ritonavir, remdesivir, and favipiravir, have been tested in clinical trials [5]. In vaccine development, numerous pharmaceutical/academic developers have developed COVID-19 vaccine candidates using various platforms, such as live-attenuated virus (e.g., Codagenix [6]), inactivated virus (e.g., Sinovac [7], Sinopharm [8]); mRNA (e.g., Pfizer [9] Moderna [10], ChulaCov19 [11], and Curevac [12]); DNA (e.g., COVIGEN [13], Inovio 
[14]); non-replicating viral vectors (e.g., AstraZeneca [15], Johnson \& Johnson [16]); and protein sub-units (e.g., Novavax[17]), and conducted clinical trials [18]. The World Health Organization (WHO) has approved several vaccines for emergency use, including AZD1222/AstraZeneca, Janssen/Johnson \& Johnson mRNA 1273/Moderna, Sinopharm, and Sinovac-CoronaVac, since 2020 [19]. The rapid transmission of COVID-19 disease along with insufficient vaccine supplies for health care workers and the absence of specific and effective prescribed drug treatments for COVID-19 patients [20] have led to some people taking herbal medicines for prevention or treatment of this disease.

Herbal medicine has been used in complementary medicine in various cultures for at least 1000 years and still has an important role in health care systems currently. The extensive use of plant sources of medicines with proven therapeutic ability for treating various diseases has led to more plant-based drug discoveries of numerous effective drugs such as vincristine, vinblastine, paclitaxel, and camptothecin (Fig. 1) [21]. Promising compounds, such as psoralens, guggulsterons, piperidines, phyllanthins, picrosides, curcuminoids, withanolides, steroidal lactones, and glycosides, have been discovered from traditional Ayuverdic medicine [22]. In addition, the discovery of the potent antimalarial drug, artemisinin (Fig. 1), has been attributed to the historical use of the plant Artemisia annua in Traditional Chinese Medicine (TCM) [23].
The perception that many herbal medicines have shown promising efficacy, safety, accessibility, environmental friendliness, and affordability has led to increased attention on traditional medicines in recent years. The efficacy of traditional herbal medicines for treating various diseases is due to the pharmacological activity of the active compounds in the plants [24]. Obviously, herbal medicine also plays essentially for prevention and treatment of COVID-19 disease in various cultures. Herbal medicines may act directly or indirectly by attacking the virus, viral-host interaction, signaling pathways, host receptors, molecular targets, immune system, and microenvironments. In TCM, herbal medicines alone or in combination with modern synthetic drugs are prescribed for COVID-19 patients [4]. The Qingfei Paidu decoction, which contains several herbs, has been used for treatment of COVID-19 patients in China [24]. Lianhua-Qingwen, Shufeng Jiedu, Huoxiang Zhengqi, and Jinhua Qinggan herbal formulas also have been used in COVID-19 treatment in TCM [25]. Herbal medicines are widely used, mostly in China and other Asian countries, such as Japan, Korea, Thailand, Vietnam, India, Bangladesh, and Indonesia. Accordingly, the aim of this review article was to describe various medicinal plants used in COVID-19 prevention and treatment from various countries in Asia as obtained from a literature search and discuss the efficacy results from laboratory testing. Additionally, the antiviral activities of
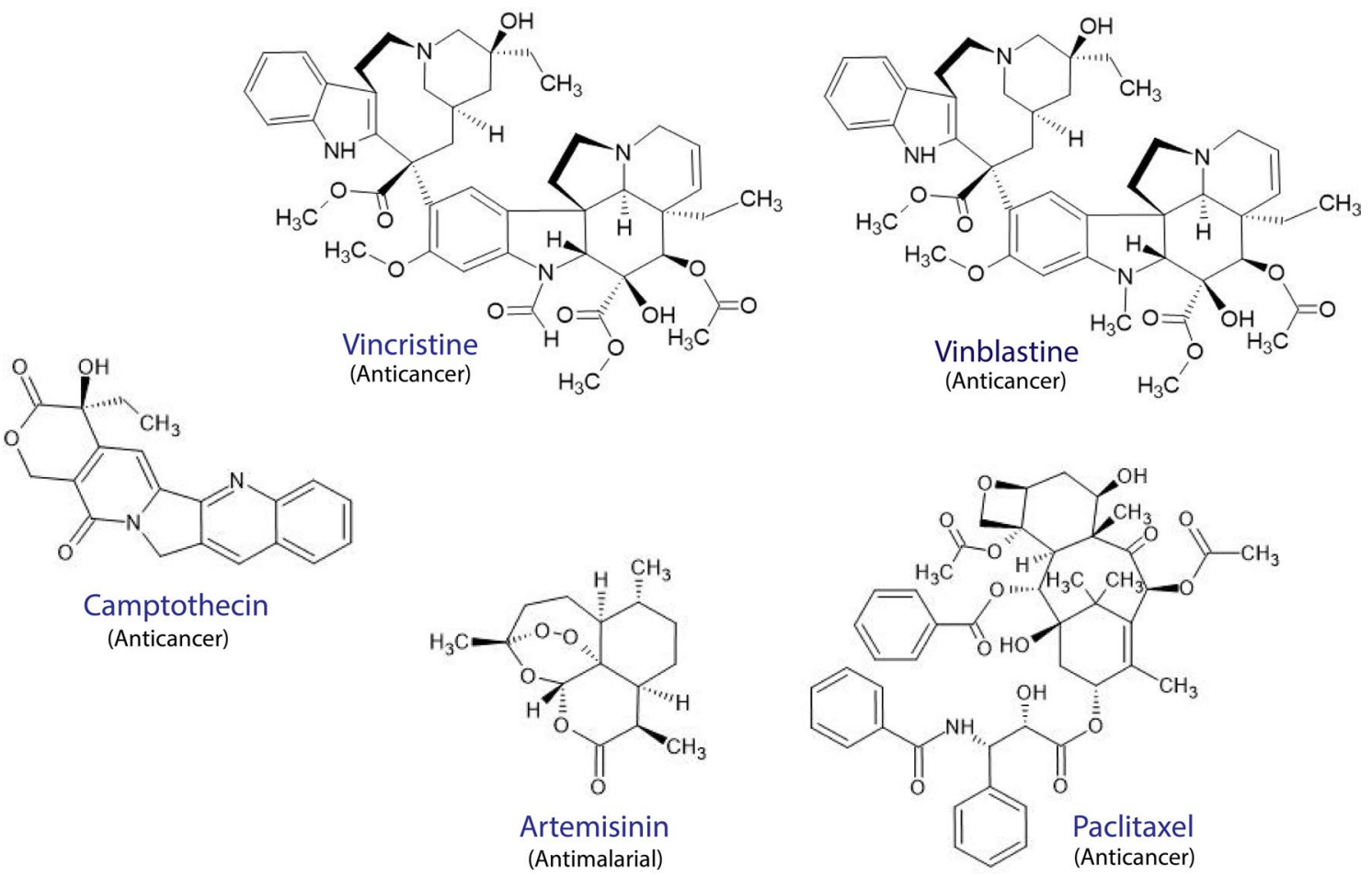

Fig. 1 Several effective modern drugs derived from traditional herbal medicine 
natural products isolated from medicinal plants against SARS-CoV-2 are discussed.

\section{Use of traditional herbal medicine during the COVID-19 pandemic and its antiviral activity against SARS-CoV-2}

The plants identified as having been used for treatment and prevention of COVID-19 diseases were extracted from literature searches of the ScienceDirect, PubMed, Scopus, and Google Scholar databases from 28th May 2021 until 20th August 2021. Plant data were retrieved from published articles about community surveys, case reports, and relevant articles that described the use of herbal medicines in Asian communities during the COVID-19 pandemic for both prevention and treatment (Tables 1,2). The species and families of plant taxa were confirmed and verified using World Flora Online database (http://www.worldfloraonline.org/), a specified plant species database maintained by the Royal Botanic Gardens and Kew and Missouri Botanical Gardens. A number of 91 plant taxa were obtained after extracting the data and then further analyzed to determine the most frequently used families and species for treatment and prevention of COVID-19.

Based on the analysis of medicinal plants used in the communities across several countries in Asia, our findings showed that the Lamiaceae family of medicinal plants was the most frequently used for prevention and treatment of COVID-19 during pandemic (Fig. 2). In addition, our findings revealed that Zingiber officinale was the most frequently used species followed by Glycyrrhiza spp. and Ocimum sanctum (Fig. 3).

Z. officinale (ginger) has been shown to be the most frequently used species in herbal medicine in communities across the countries studied. The crude extract of this herb reportedly exhibited antiviral activity against SARS-CoV-2 in a Vero E6 cell model, with $\mathrm{IC}_{50}$ of $29.19 \mu \mathrm{M}$. The main phenolic compound in ginger, 6-gingerol, only showed an $\mathrm{IC}_{50}$ of $\leq 100 \mu \mathrm{M}$ [26], which suggests that the efficacy of Z. officinale may depend on mechanisms that do not involve 6-gingerol for suppressing COVID-19 symptoms, do not directly attack the virus, or that is synergistic with other herbs to achieve a better therapeutic effect. $Z$. officinale is a spice in which gingerols and shogaol are the active compounds thought to provide health benefits. This herb possesses a range of medicinal benefits, including antiviral activity against feline calicivirus, human respiratory syncytial virus, influenza A, and H9N2, and its activity for stimulating tumor necrosis factor alpha (TNF- $\alpha$ ) is postulated as a first-line defense for virus infection [27].

Along with ginger, Glycyrrhiza spp. is a frequently used medicinal plant for COVID-19 treatment. This herb is mostly included in various formulas in TCM for COVID-19 treatment, such as Ma Xing Shi Gan, Da Yuan Yin, and Lianhua-Qingwen. The Lianhua-Qingwen formula contains various herbs, including Glycyrrhiza uralensis, and reportedly exhibits inhibitory activity against SARS-CoV-2 (Table 2). On the other hand, the aqueous extract of Glycyrrhiza glabra root reportedly exhibits inhibitory activity against SARSCoV-2 infected Vero E6 cells. The extract has shown antiviral effects at $2 \mathrm{mg} / \mathrm{ml}$, which is lower than its toxic concentration. Glycyrrhizin, as a triterpenoid glycoside, has also shown viral blocking ability at $0.5 \mathrm{mg} / \mathrm{ml}$ and $1 \mathrm{mg} / \mathrm{ml}$ in the pre-entry and post-entry conditions, respectively. In addition, no cytotoxic effect has been found at $\leq 4 \mathrm{mg} / \mathrm{ml}$. The half-maximal effective concentration $\left(\mathrm{EC}_{50}\right)$ of this compound reportedly is $0.44 \mathrm{mg} / \mathrm{ml}$. Glycyrrhizin has also been shown to significantly reduce the SARS-CoV-2 RNA level [28]. An in silico study showed that this compound binds to the ACE2 receptor, which possibly blocks viral entry [29].

\section{Molecular drug targets for COVID-19}

SARS-CoV-2 is a novel coronavirus that belongs to the Coronavirinae family. Coronaviruses are RNA viruses that have a spherically shaped envelope $100-160 \mathrm{~nm}$ in diameter. The genome size is $27-32 \mathrm{~kb}$. The $3^{\prime}$ end of the genome encodes structural proteins, such as envelope (E), spike glycoprotein $(\mathrm{S})$, nucleocapsid $(\mathrm{N})$, and membrane glycoprotein $(\mathrm{M})$, and the $5^{\prime}$ end encodes polyproteins involved in replication and transcription [20]. SARS-CoV-2 can enter the host cell via various receptors, such as ACE2, aminopeptidase N (APN), and dipeptidyl peptidase 4 (DPP4). Hence, these three receptors are promising targets for treatment of COVID-19 infection. ACE2 is known to be prevalent in alveolar cells. In addition, males are known to express higher levels of ACE2 than females. The expression of ACE2 can be increased by binding of the $\mathrm{S}$ protein of SARS-CoV-2 to ACE2. On the other hand, DPP4 mediates entry of the virus into the host cell via directed cell-cell fusion, whereas APN promotes cross-species transmission of SARS-CoV-2, which is involved in receptor binding [30].

The ACE2 receptor, S protein, RNA-dependent RNA polymerase ( $\mathrm{RdRp})$, papain-like protease ( $\left.\mathrm{PL}^{\mathrm{pro}}\right)$, and 3-chymotrypsin-like protease $\left(3 \mathrm{CL}^{\text {pro }}\right.$ or main protease $\left.\left(\mathrm{M}^{\text {pro }}\right)\right)$ are known to be potential targets for COVID-19 drugs because these biomaterials are essential for viral invasion of the host cell [4]. SARS-CoV-2 invades the host cell by binding of its $\mathrm{S}$ protein to the ACE2 receptor of the host cell followed by $S$ protein cleavage by transmembrane serine protease 2 (TMPRSS2). Next, genomic RNA is released into the host cell cytoplasm and undergoes translation of polyprotein (ppa1/ab), which is cleaved further by viral $\mathrm{M}^{\mathrm{pro}}$ and $\mathrm{PL}^{\mathrm{pro}}$ into non-structural protein (nsp). The nsp protein then interacts with RdRp for building the replication-transcription 
Table 1 Herbal medicines used during the COVID-19 pandemic based on guidelines, community surveys, and case reports

\begin{tabular}{|c|c|c|c|}
\hline Family & Species & Country origin & References \\
\hline Amaryllidaceae & Allium sativum & Vietnam & {$[51]$} \\
\hline Apiaceae & Centella asiatica & Vietnam & {$[51]$} \\
\hline Apiaceae & Saposhnikovia divaricata & China & {$[52]$} \\
\hline Apiaceae & Glehnia spp. & China & {$[52]$} \\
\hline Araliaceae & Panax ginseng & Vietnam & {$[51]$} \\
\hline Asparagaceae & Ophiopogon spp. & China & {$[52]$} \\
\hline Brassicaceae & Isatis indigotica & China & {$[52]$} \\
\hline Campanulaceae & Platycodon grandiflorus & China & {$[52]$} \\
\hline Caprifoliaceae & Lonicera japonicae & China & {$[52]$} \\
\hline Compositae & Artemisia vulgaris & Vietnam & {$[51]$} \\
\hline Compositae & Cynara cardunculus & Vietnam & {$[51]$} \\
\hline Compositae & Atractylodes macrocephalae & China & {$[52]$} \\
\hline Compositae & Atractylodes spp. & China & {$[52]$} \\
\hline Compositae & Eupatorium spp. & China & {$[52]$} \\
\hline Cucurbitaceae & Citrullus lanatus & Bangladesh & {$[53]$} \\
\hline Dryopteridaceae & Cyrtomium fortune & China & {$[52]$} \\
\hline Lamiaceae & Perilla frutescens & Vietnam & {$[51]$} \\
\hline Lamiaceae & Plectranthus amboinicus & Vietnam & {$[51]$} \\
\hline Lamiaceae & Elsholtzia ciliata & Vietnam & {$[51]$} \\
\hline Lamiaceae & Ocimum tenuiflorum & India & {$[54]$} \\
\hline Lamiaceae & Vitex negundo & Bangladesh & {$[53]$} \\
\hline Lamiaceae & Pogostemon cablin & China & {$[52]$} \\
\hline Lamiaceae & Perilla spp. & China & {$[52]$} \\
\hline Leguminosae & Glycyrrhiza spp. & Vietnam & {$[51]$} \\
\hline Leguminosae & Astragalus spp. & China & {$[52]$} \\
\hline Leguminosae & Glycyrrhiza spp. & China & {$[52]$} \\
\hline Menispermaceae & Tinospora cordifolia & India & {$[54]$} \\
\hline Moraceae & Morus alba & China & {$[52]$} \\
\hline Oleaceae & Forsythia suspensa & China & {$[52]$} \\
\hline Phyllanthaceae & Emblica officinalis & India & {$[54]$} \\
\hline Piperaceae & Piper lolot & Vietnam & {$[51]$} \\
\hline Poaceae & Phragmites communis & China & {$[52]$} \\
\hline Poaceae & Coix lacryma-jobi & China & {$[52]$} \\
\hline Ranunculaceae & Nigella sativa & Bangladesh & {$[53]$} \\
\hline Rutaceae & Citrus reticulata & China & {$[52]$} \\
\hline Saururaceae & Houttuynia cordata & Vietnam & {$[51]$} \\
\hline Xanthorrhoeaceae & Aloe vera & Vietnam & {$[51]$} \\
\hline Zingiberaceae & Zingiber officinale & Vietnam & {$[51]$} \\
\hline Zingiberaceae & Curcuma longa & India & {$[54]$} \\
\hline
\end{tabular}

complex. After entering the cell, with RdRp, the virus takes over genetic reproduction to produce new viral RNA. Cleaved glycoproteins by virus proteases ( $\mathrm{PL}^{\text {pro }}$ and $\mathrm{M}^{\text {pro }}$ ) are then produced, and the viral material is assembled so that it can synthesize new viral particles to further infect other host cells [4, 31, 32].

ACE2 is also the proposed drug target for preventing SARS-CoV-2 infection. This enzyme is a transmembrane protein, localized in alveolar epithelial cells, vascular endothelial cells, small intestine epithelial cells, and renal tubular epithelial cells. ACE2 functions by cleaving the C-terminal amino acid residue of angiotensin II (Ang II), which maintains the balance of generated Ang II. Furthermore, ACE2 is known to be the receptor for $\mathrm{S}$ proteins of SARS-Cov-2; hence, inhibition of this enzyme may be a drug target for preventing SARS-CoV-2 infection [2, 33]. The expressed $\mathrm{S}$ protein of SARS-CoV-2 functions by binding to the ACE2 receptor. Infection by this virus can be through two pathways: endocytic and direct fusion. In the endocytic pathway, cleavage of $\mathrm{S}$ proteins is mediated by 
Table 2 Use of formulated herbal medicines for prevention and treatment during the COVID-19 pandemic from community case reports and its antiviral activity against SARS-CoV-2

\begin{tabular}{|c|c|c|c|c|c|c|c|}
\hline Formula & Country origin & Family & Species & $\begin{array}{l}\text { Usage report } \\
\text { in commu- } \\
\text { nity }\end{array}$ & References & $\begin{array}{l}\text { Antiviral activity } \\
\text { against SARS-CoV-2 }\end{array}$ & References \\
\hline Lianhua-Qingwen & China & $\begin{array}{l}\text { Oleaceae } \\
\text { Caprifoliaceae } \\
\text { Ephedraceae } \\
\text { Dryopteridaceae } \\
\text { Rosaceae } \\
\text { Crassulaceae } \\
\text { Polygonaceae } \\
\text { Saururaceae } \\
\text { Brassicaceae } \\
\text { Lamiaceae } \\
\text { Lamiaceae } \\
\text { Leguminosae }\end{array}$ & $\begin{array}{l}\text { Forsythia suspensa } \\
\text { Lonicera japonica } \\
\text { Ephedra sinica } \\
\text { Dryopteris crassirhi- } \\
\quad \text { zoma } \\
\text { Prunus armeniaca } \\
\text { Rhodiola rosea } \\
\text { Rheum palmatum } \\
\text { Houttuynia cordata } \\
\text { Isatis indigotica } \\
\text { Pogostemon cablin } \\
\text { Mentha haplocalyx } \\
\text { Glycyrrhiza uralensis }\end{array}$ & Yes & {$[1]$} & $\begin{array}{l}\text { In an in vitro model } \\
\text { using infected Vero } \\
\text { E6 cell lines with } \\
\text { SARS-CoV-2, an } \\
\text { herbal formula } \\
\text { inactivated virus rep- } \\
\text { lication, altered virus } \\
\text { morphology, and } \\
\text { reduced pro-inflam- } \\
\text { matory cytokines }\end{array}$ & {$[1,55,56]$} \\
\hline $\begin{array}{l}\text { Pudilan Xiaoyan } \\
\text { Oral Liquid } \\
\text { (PDL) }\end{array}$ & China & $\begin{array}{l}\text { Brassicaceae } \\
\text { Compositae } \\
\text { Lamiaceae } \\
\text { Papaveraceae }\end{array}$ & $\begin{array}{l}\text { Isatis indigotica } \\
\text { Taraxacum mongoli- } \\
\text { cum } \\
\text { Scutellaria baicalensis } \\
\text { Corydalis bungeana }\end{array}$ & N/D & - & $\begin{array}{l}\text { Inhibit SARS-CoV-2 } \\
\text { replication in Vero } \\
\text { E6 cells with EC } \text { E0 }_{50} \\
1.078 \mathrm{mg} / \mathrm{ml} \text { and } \\
\text { in vivo study with } \\
\text { hACE2 mice model } \\
\text { infected SARS- } \\
\text { CoV-2 revealed that } \\
\text { this formula is able } \\
\text { to relieve symp- } \\
\text { toms of pneumonia, } \\
\text { chronic obstructive } \\
\text { pulmonary disease, } \\
\text { and asthma }\end{array}$ & {$[1,57]$} \\
\hline Shuanghuanglian & China & $\begin{array}{l}\text { Caprifoliaceae } \\
\text { Lamiaceae } \\
\text { Oleaceae }\end{array}$ & $\begin{array}{l}\text { Lonicera japonica } \\
\text { Scutellaria baicalensis } \\
\text { Forsythia suspense }\end{array}$ & N/D & - & $\begin{array}{l}\text { Inhibit SARS-CoV-2 } \\
\text { in Vero E6 cells, with } \\
\text { an } \mathrm{EC}_{50} 0.93 \mu \mathrm{l} / \mathrm{ml}\end{array}$ & [45] \\
\hline Ma Xing Shi Gan & China & $\begin{array}{l}\text { Rosaceae } \\
\text { Leguminosae } \\
\text { Ephedraceae }\end{array}$ & $\begin{array}{l}\text { Prunus armeniaca } \\
\text { Glycyrrhiza spp. } \\
\text { Ephedra sp. }\end{array}$ & Yes & {$[58]$} & N/D & - \\
\hline Da Yuan Yin & China & $\begin{array}{l}\text { Magnoliaceae } \\
\text { Arecaceae } \\
\text { Zingiberaceae } \\
\text { Lamiaceae } \\
\text { Leguminosae } \\
\text { Asparagaceae } \\
\text { Dioscoreaceae }\end{array}$ & $\begin{array}{l}\text { Magnolia officinalis } \\
\text { Areca catechu } \\
\text { Amomum tsao-ko } \\
\text { Scutellaria baicalensis } \\
\text { Glycyrrhiza uralensis } \\
\text { Anemarrhena aspho- } \\
\text { deloides } \\
\text { Dioscorea polystachya }\end{array}$ & Yes & {$[58]$} & N/D & - \\
\hline Qing Fei Pai Du & China & $\begin{array}{l}\text { Ephedraceae } \\
\text { Araceae } \\
\text { Zingiberaceae } \\
\text { Rutaceae }\end{array}$ & $\begin{array}{l}\text { Ephedra sp. } \\
\text { Pinellia ternata } \\
\text { Zingiber officinale } \\
\text { Citrus aurantium }\end{array}$ & Yes & {$[1,58]$} & N/D & - \\
\hline Yu Ping Feng San & China & $\begin{array}{l}\text { Leguminosae } \\
\text { Compositae } \\
\text { Apiaceae }\end{array}$ & $\begin{array}{l}\text { Astragalus membrana- } \\
\text { ceus } \\
\text { Atractylodes macro- } \\
\text { cephala } \\
\text { Saposhnikovia divari- } \\
\text { cata }\end{array}$ & Yes & {$[1,58]$} & N/D & - \\
\hline
\end{tabular}


Table 2 (continued)

\begin{tabular}{|c|c|c|c|c|c|c|c|}
\hline Formula & Country origin & Family & Species & $\begin{array}{l}\text { Usage report } \\
\text { in commu- } \\
\text { nity }\end{array}$ & References & $\begin{array}{l}\text { Antiviral activity } \\
\text { against SARS-CoV-2 }\end{array}$ & References \\
\hline \multirow[t]{4}{*}{ Ayush Kwath } & \multirow[t]{4}{*}{ India } & Lamiaceae & Ocimum sanctum & \multirow[t]{4}{*}{ Yes } & \multirow[t]{4}{*}[59]{} & \multirow[t]{4}{*}{$\mathrm{N} / \mathrm{D}$} & \multirow[t]{4}{*}{-} \\
\hline & & Lauraceae & $\begin{array}{l}\text { Cinnamomum zeylani- } \\
\text { cum }\end{array}$ & & & & \\
\hline & & Zingiberaceae & Zingiber officinale & & & & \\
\hline & & Piperaceae & Piper nigrum & & & & \\
\hline \multirow[t]{3}{*}{ N/D } & \multirow[t]{3}{*}{ Bangladesh } & Zingiberaceae & Zingiber officinale & \multirow[t]{3}{*}{ Yes } & \multirow[t]{3}{*}[60]{} & \multirow[t]{3}{*}{ N/D } & \multirow[t]{3}{*}{-} \\
\hline & & Myrtaceae & Syzygium aromaticum & & & & \\
\hline & & Lauraceae & Cinnamomum verum & & & & \\
\hline \multirow[t]{5}{*}{ N/D } & \multirow[t]{5}{*}{ Bangladesh } & Zingiberaceae & Zingiber officinale & \multirow[t]{5}{*}{ Yes } & \multirow[t]{5}{*}[60]{} & \multirow[t]{5}{*}{$\mathrm{N} / \mathrm{D}$} & \multirow[t]{5}{*}{-} \\
\hline & & Myrtaceae & Syzygium aromaticum & & & & \\
\hline & & Lauraceae & Cinnamomum verum & & & & \\
\hline & & Lamiaceae & Ocimum sanctum & & & & \\
\hline & & Theaceae & Camellia sinensis & & & & \\
\hline \multirow[t]{2}{*}{ N/D } & \multirow[t]{2}{*}{ Bangladesh } & Zingiberaceae & Zingiber officinale & \multirow[t]{2}{*}{ Yes } & \multirow[t]{2}{*}[60]{} & \multirow[t]{2}{*}{ N/D } & \multirow[t]{2}{*}{-} \\
\hline & & Theaceae & Camellia sinensis & & & & \\
\hline \multirow[t]{2}{*}{ N/D } & \multirow[t]{2}{*}{ Bangladesh } & Lamiaceae & Ocimum sanctum & \multirow[t]{2}{*}{ Yes } & \multirow[t]{2}{*}[53]{} & \multirow[t]{2}{*}{ N/D } & \multirow[t]{2}{*}{-} \\
\hline & & Piperaceae & Piper nigrum & & & & \\
\hline \multirow[t]{2}{*}{ N/D } & \multirow[t]{2}{*}{ Bangladesh } & Zingiberaceae & Zingiber officinale & \multirow[t]{2}{*}{ Yes } & {$[53]$} & $\mathrm{N} / \mathrm{D}$ & - \\
\hline & & Rutaceae & Citrus limon & & & & \\
\hline N/D & Bangladesh & Lamiaceae & Ocimum sanctum & Yes & {$[53]$} & $\mathrm{N} / \mathrm{D}$ & - \\
\hline & & Lamiaceae & Vitex negundo & & & & \\
\hline & & Rutaceae & Citrus limon & & & & \\
\hline & & Zingberaceae & Zingiber officinale & & & & \\
\hline & & Ranunculaceae & Nigella sativa & & & & \\
\hline
\end{tabular}

cathepsin $\mathrm{B} / \mathrm{L}$ in lysosomes. On the other hand, virus entry via direct fusion is mediated by TMPRSS2 for cleavage of $S$ proteins. The cleavage of $S$ viral protein by these two mediators is a critical factor that enables RNA viruses to enter the cytosol of host cells. Hence, these two proteases and the ACE2 receptor determine the susceptibility to SARSCoV-2 infection $[31,34]$. On the other hand, $\mathrm{M}^{\text {pro }} / 3 \mathrm{CL}^{\text {pro }}$ have essential roles in the viral polyprotein maturation process [1]. 3CL $\mathrm{CL}^{\text {pro }}$ is known to be the main drug target of coronaviruses, mainly inhibits replication of SARS-CoV-2, and is required for viral replication through cleavage of viral polyproteins to undergo the life cycle. Hence, $3 \mathrm{CL}^{\text {pro }}$ is a target of antiviral drugs [35].

\section{Identified medicinal plants and their active compounds against SARS-CoV-2}

Various medicinal plants and isolated compounds have been tested against SARS-CoV-2 and revealed some promising activities based on in vitro and in cell studies (Tables 3, 4). Several crude drugs derived from mostly
Asian herbs have been tested for anti-SARS-CoV-2 activity in some infected cells and protein targets.

Antiviral drugs or therapy for SARS-CoV-2 can be achieved by targeting the virus itself or enhancing immunity, which may help to suppress viral replication. Inhibition of viral replication may be through a mechanism that blocks the virus from entering human cells (preventing binding of the virus' $S$ protein to the ACE2 receptor) or by attacking the viral enzymes that are essential for its replication. In addition, the drug can act as an inhibitor of various structural proteins, such as $\mathrm{M}^{\text {pro }}$, $\mathrm{PL}^{\text {pro }}$, helicase, serine protease, and RdRp [2]. Severe COVID-19 patients also may be treated by blocking the cytokine storm through suppression of pro-inflammatory cytokines. In severe COVID-19 patients, the cytokine storm occurs in response to significantly elevated levels of the inflammatory cytokines, such as interleukin (IL)-6, IL-7, IL8, IL9, IL-10, IL-1B, IL-1Ra, granulocyte macrophage colonystimulating factor, fibroblast growth factor, IFN- $\gamma, \mathrm{TNF}-\alpha$, platelet-derived growth factor, monocyte chemoattractant protein, macrophage inflammatory protein $1-\alpha$, and vascular endothelial growth factor [4]. 


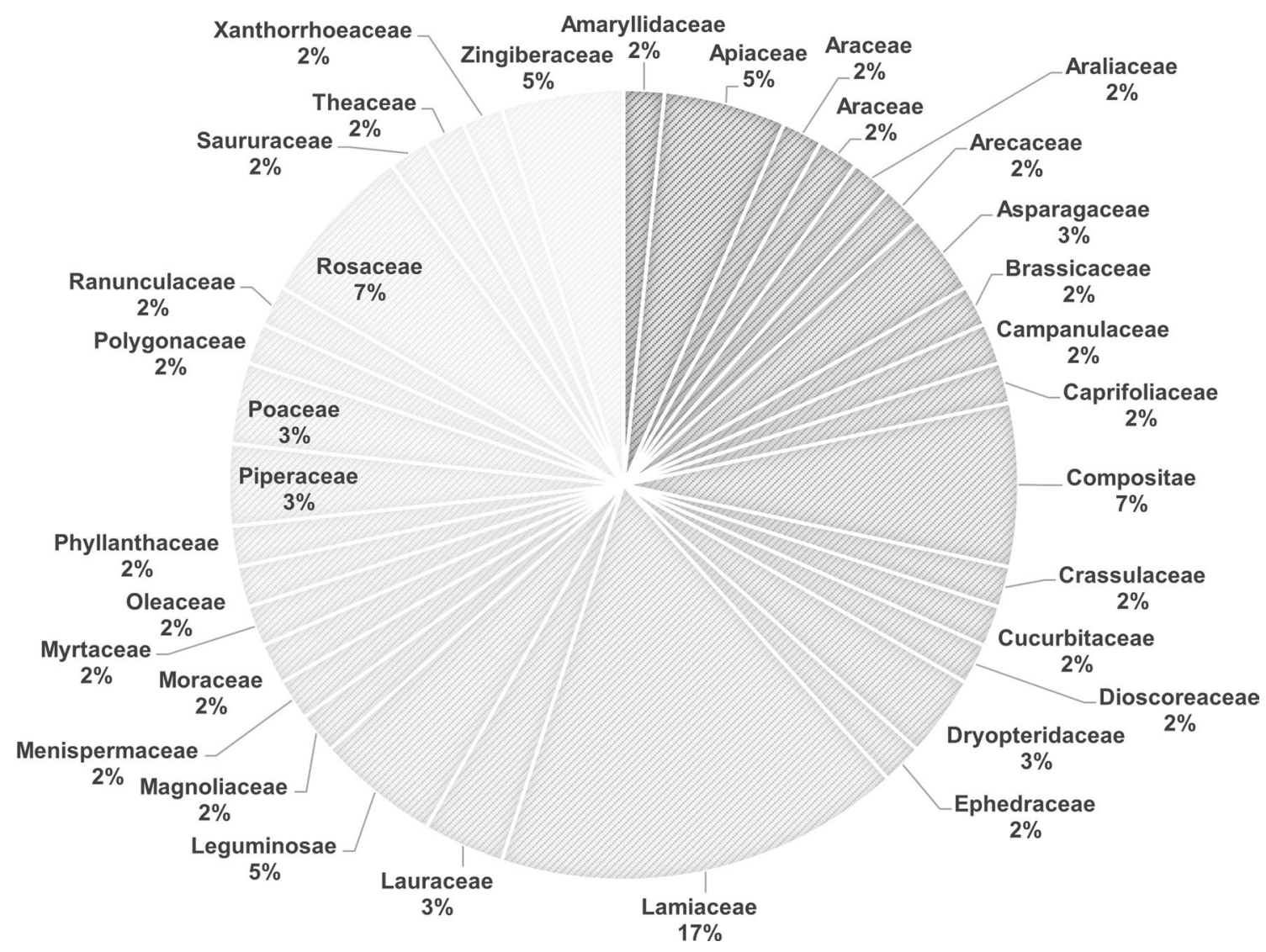

Fig. 2 Frequently used families of medicinal herbs for prevention and treatment of COVID-19

Fig. 3 Frequently used species in herbal medicines against COVID-19

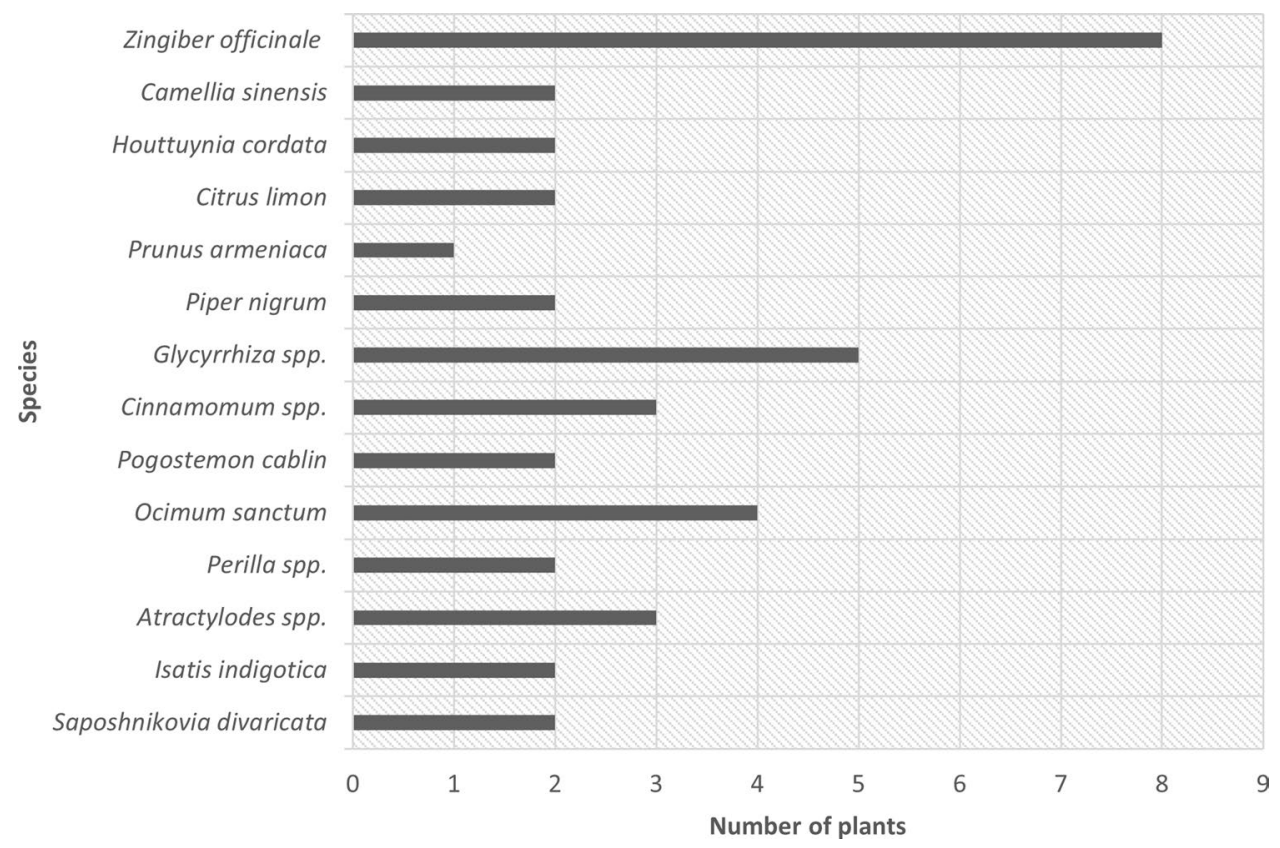

Numerous existing drugs have been repurposed for treating COVID-19 disease, such as chloroquine, remdesivir, favipiravir, and umifenovir [30]. However, currently there is no effective treatment that has been approved by regulators [36]. Chloroquine, an antimalarial drug, possesses antiviral activity, including against coronaviruses, and has been 
Table 3 Anti-SARS-CoV-2 activity of medicinal plants (crude drugs)

\begin{tabular}{|c|c|c|c|c|c|c|}
\hline Origin & Species & Family & $\mathrm{IC}_{50}(\mu \mathrm{g} / \mathrm{ml})$ & $\mathrm{EC}_{50}(\mu \mathrm{g} / \mathrm{ml})$ & Experimental result & References \\
\hline Thailand & Andrographis paniculata & Acanthaceae & 0.036 & - & SARS-CoV-2 infected Calu-3 cells & {$[37]$} \\
\hline Thailand & Andrographis paniculata & Acanthaceae & 68.06 & - & SARS-CoV-2 infected Vero E6 cells & {$[52]$} \\
\hline China & Scutellaria baicalensis & Lamiaceae & - & 0.74 & SARS-CoV-2 infected Vero cells & {$[43]$} \\
\hline Korea & Platycodon grandiflorum & Campanulaceae & 5,010 & - & $\begin{array}{l}\text { In vitro study using } \mathrm{ACE}^{+} \text {cells using } \mathrm{H} 1299 \\
\text { cell }\end{array}$ & {$[34]$} \\
\hline Thailand & Boesenbergia rotunda & Zingiberaceae & 3.62 & - & SARS-CoV-2 infected Vero E6 cells & {$[26]$} \\
\hline India & Camellia sinensis & Theaceae & $8.9 \pm 0.5$ & - & SARS-CoV-2 $\mathrm{M}^{\mathrm{pro}} / 3 \mathrm{CL}^{\text {pro }}$ & {$[61]$} \\
\hline India & Terminalia chebula & Combretaceae & $8.8 \pm 0.5$ & - & SARS- CoV-2 $\mathrm{M}^{\mathrm{pro}} / 3 \mathrm{CL}^{\mathrm{pro}}$ & {$[61]$} \\
\hline Thailand & Zingiber officinale & Zingiberaceae & 29.19 & - & SARS-CoV-2 infected Vero E6 cells & [26] \\
\hline Germany & Glycyrrhiza glabra & Fabaceae & - & - & $\begin{array}{l}\text { Blocking SARS-CoV-2 replication at pre-entry } \\
\text { stage in infected Vero E6 cells at } 0.5 \mathrm{mg} / \mathrm{ml}\end{array}$ & {$[28]$} \\
\hline China & Reynoutria sachalinensis & Polygonaceae & 4.013 & - & SARS-CoV-2 $\mathrm{M}^{\mathrm{pro}} / 3 \mathrm{CL}^{\text {pro }}$ & {$[62]$} \\
\hline China & Reynoutria japonica & Polygonaceae & 7.877 & - & SARS-CoV-2 $\mathrm{M}^{\mathrm{pro}} / 3 \mathrm{CL}^{\mathrm{pro}}$ & {$[62]$} \\
\hline China & Lycoris radiata & Amaryllidaceae & - & $2.4 \pm 0.2$ & SARS-CoV infected Vero E6 cells & {$[63]$} \\
\hline China & Artemisia аппиа & Compositae & - & $34.5 \pm 2.6$ & SARS-CoV infected Vero E6 cells & {$[63]$} \\
\hline China & Pyrrosia lingua & Polypodiaceae & - & $43.2 \pm 14.1$ & SARS-CoV infected Vero E6 cells & {$[63]$} \\
\hline China & Lindera aggregata & Lauraceae & - & $88.2 \pm 7.7$ & SARS-CoV infected Vero E6 cells & {$[63]$} \\
\hline
\end{tabular}

considered as a possible antiviral drug for SARS-CoV-2 and been tested against COVID-19 in China. Chloroquine can block cathepsin by increasing lysosomal $\mathrm{pH}$ and modulating pro-inflammatory cytokines, including $\mathrm{TNF}-\alpha$ and IL-6. However, the failure of this drug in a clinical trial was attributed to its inability to block TMPRSS2-mediated viral entry [30, 34]. Remdesivir, an antiviral drug for Ebola and Marburg virus also has been tested in a clinical trial due to its ability to attack coronaviruses by inhibiting RdRp. The influenza drug, favipiravir, can terminate incorporation of viral RNA into the host cell. Umifemovir/Arbidol, which are influenza $\mathrm{A}$ and $\mathrm{B}$ drugs, also have been reported to block viral fusion into host cell membranes [30]. Additionally, lopinavir reportedly blocks $3 \mathrm{CL}^{\text {pro }}$ of the virus, whereas both camostat mesylate and nafamostat reportedly inhibit viral entry and act as TMPRSS 2 inhibitors. Chloroquine and hydroxychloroquine have also shown inhibition of viral entry [32].

The present review focuses on compounds isolated from medicinal plants against SARS-CoV-2 shown to be active in vitro and in cell studies (Table 4), and several compounds show promising antiviral activity as compared with several FDA-approved drugs as mentioned above (Figs. 4, 5). Among the other tested compounds, andrographolide has shown promising potency $\left(\mathrm{IC}_{50}\right.$ of $0.034 \mu \mathrm{M}$, against SARS-CoV-2-infected Calu-3 cells). Andrographolide is a major active compound isolated from Andrographis paniculata that has been used for a long time in Thai traditional medicine for diarrhea, common cold, fever, and viral infections. This bicyclic diterpene lactone exhibits various pharmacological properties, such as antioxidant, anticancer, anti-inflammatory, antimicrobial, cardiovascular protection, hepatoprotection, and immunomodulatory. Andrographolide has shown broad-spectrum antiviral activity against various viral infections, such as influenza, hepatitis, HIV, chikungunya, herpes, and HPV. Based on an in vitro assay, the extract and its active compound exhibited anti-SARSCoV-2 activity. In an enzyme-based assay, andrographolide inhibited $\mathrm{M}^{\text {pro }}$ (the SARS-CoV-2 main protease), with an $\mathrm{IC}_{50}$ of $15 \mu \mathrm{M}$, possibly through formation of a covalent bond with the active site at the Cys145 amino acid residue. It is postulated that this compound would attack the virus through multiple pathways, including viral entry, replication, protein synthesis, and protein expression. Andrographolide has also shown binding affinity with the $S$ protein and the ACE2 receptor, hence, it may inhibit viral entry. This compound is thought to be more potent in the late phase of the SARS-CoV-2 life cycle than in genome replication and protein expression [37-40]. The 50\% cytotoxic concentration $\left(\mathrm{CC}_{50}\right)$ of this compound to various normal cell lines from various organs, including liver, kidney, intestine, lung, and brain (HepG-2/imHC, HK-2, Caco-2, Calu-3, and SH-SY5Y, respectively), ranges from 13.2 to $81.5 \mu \mathrm{M}$ [37].

A prenylated cyclohexenyl chalcone, panduratin A, exhibited potent antiviral activity against SARS-CoV-2 in both pre-entry and post-infection. This compound has been isolated from a fingerroot of Boesenbergia rotunda that is commonly used in Southeast Asia and China as a culinarily spice. The rhizome has various pharmacological properties, such as antibacterial, antitumor, anti-allergic, and antioxidant. Panduratin $\mathrm{A}$, as a major active compound, has shown antiviral activity against HIV [41] and 
Table 4 Anti-SARS-CoV-2 activity of active compounds isolated from medicinal plants

\begin{tabular}{|c|c|c|c|c|c|c|c|}
\hline Plant origin & Compound & Plant & Family & $\mathrm{IC}_{50}(\mu \mathrm{M})$ & $\mathrm{EC}_{50}(\mu \mathrm{M})$ & Model & References \\
\hline Thailand & 6-Gingerol & $\begin{array}{l}\text { Zingiber offici- } \\
\text { nale }\end{array}$ & Zingiberaceae & 1.38 & - & $\begin{array}{l}\text { SARS-CoV-2 NP } \\
\text { mAb Plaque } \\
\text { reduction assay } \\
\text { in Vero cells }\end{array}$ & {$[26]$} \\
\hline Thailand & 6-Gingerol & $\begin{array}{l}\text { Zingiber offici- } \\
\text { nale }\end{array}$ & Zingiberaceae & $>100$ & - & $\begin{array}{l}\text { SARS-CoV-2 } \\
\text { infected Vero } \\
\text { E6 cells }\end{array}$ & [26] \\
\hline Thailand & Andrographolide & $\begin{array}{c}\text { Andrographis } \\
\text { paniculata }\end{array}$ & Acanthaceae & 0.034 & - & $\begin{array}{l}\text { SARS-CoV-2 in } \\
\text { Calu- } 3 \text { cells }\end{array}$ & {$[37]$} \\
\hline Thailand & Andrographolide & $\begin{array}{c}\text { Andrographis } \\
\text { paniculata }\end{array}$ & Acanthaceae & 6.58 & - & $\begin{array}{l}\text { SARS-CoV-2 } \\
\text { infected Vero } \\
\text { E6 cells }\end{array}$ & {$[52]$} \\
\hline Thailand & Andrographolide & $\begin{array}{c}\text { Andrographis } \\
\text { paniculata }\end{array}$ & Acanthaceae & 0.28 & - & $\begin{array}{l}\text { NP mAb SARS- } \\
\text { CoV-2 }\end{array}$ & [26] \\
\hline Asia & Artemisinin & Artemisia аппиа & Compositae & - & $64.45 \pm 2.58$ & $\begin{array}{l}\text { SARS-CoV-2 } \\
\text { infected Vero } \\
\text { E6 cells }\end{array}$ & {$[64]$} \\
\hline China & Baicalein & $\begin{array}{l}\text { Scutellaria bai- } \\
\text { calensis }\end{array}$ & Lamiaceae & 0.39 & - & $\begin{array}{l}\text { SARS-CoV-2 } \\
\text { infected Vero } \\
\text { cells }\end{array}$ & [43] \\
\hline \multirow[t]{2}{*}{ China } & Baicalein & $\begin{array}{l}\text { Scutellaria bai- } \\
\quad \text { calensis }\end{array}$ & Lamiaceae & $\begin{array}{r}0.94 \pm 0.20 \text { (in } \\
\left.\text { vitro } 3 \mathrm{CL}^{\text {pro }}\right)\end{array}$ & $\begin{array}{l}2.94 \pm 1.19 \text { (in } \\
\text { Vero E6 cells) }\end{array}$ & $\begin{array}{l}\text { SARS-CoV-2 } \\
\text { infected Vero } \\
\text { E6 and in vitro } \\
\text { assay against } \\
\text { SARS-CoV-2 } \\
\text { M }^{\text {pro }} / 3 \mathrm{CL}^{\text {pro }}\end{array}$ & [45] \\
\hline & Baicalin & & & $\begin{array}{c}6.41 \pm 0.95 \text { (in } \\
\left.\text { vitro } 3 \mathrm{CL}^{\text {pro }}\right)\end{array}$ & $\begin{array}{r}27.87 \pm 0.04 \text { (in } \\
\text { Vero E6 cells) }\end{array}$ & $\begin{array}{l}\text { SARS-CoV-2 } \\
\text { infected Vero } \\
\text { E6 and in vitro } \\
\text { assay against } \\
\text { SARS-CoV-2 } \\
\text { M }^{\text {pro }} / 3 \mathrm{CL}^{\text {pro }}\end{array}$ & \\
\hline Korea & Cannabidiol & Cannabis sativa & Cannabaceae & 7.91 & - & $\begin{array}{l}\text { SARS-CoV-2 } \\
\text { infected Vero } \\
\text { cells }\end{array}$ & {$[65]$} \\
\hline Asia & Cepharanthine & $\begin{array}{l}\text { Stephania ceph- } \\
\quad \text { alanta }\end{array}$ & Menispermaceae & 4.47 & - & $\begin{array}{l}\text { SARS-CoV-2 } \\
\text { infected Vero } \\
\text { cells }\end{array}$ & [47] \\
\hline China & Chlorogenic acid & Lonicera japonica & Caprifoliaceae & $39.48 \pm 5.51$ & - & $\begin{array}{l}\text { SARS-CoV-2 } \\
\mathrm{M}^{\text {pro }} / 3 \mathrm{CL}^{\text {pro }}\end{array}$ & [45] \\
\hline N/D & Digitoxin & $\begin{array}{l}\text { Digitalis purpu- } \\
\quad \text { rea }\end{array}$ & Plantaginaceae & 0.23 & - & $\begin{array}{l}\text { SARS-CoV-2 } \\
\text { infected Vero } \\
\text { cells based on } \\
\text { cytopathic effect }\end{array}$ & [47] \\
\hline N/D & Digoxin & $\begin{array}{l}\text { Digitalis purpu- } \\
\quad \text { rea }\end{array}$ & Plantaginaceae & 0.19 & - & $\begin{array}{l}\text { SARS-CoV-2 } \\
\text { infected Vero } \\
\text { cells based on } \\
\text { cytopathic effect }\end{array}$ & [47] \\
\hline Asia & $\begin{array}{l}\text { Epigallocatechin } \\
\text { gallate (EGCG) }\end{array}$ & Camellia sinensis & Theaceae & 16.53 & - & $\begin{array}{l}\text { In vitro assay } \\
\text { against } \\
\text { SARS-CoV-2 } \\
\text { M }^{\text {pro }} / 3 \mathrm{CL}^{\text {pro }}\end{array}$ & {$[35]$} \\
\hline Germany & Glycyrrhizin & $\begin{array}{l}\text { Glycyrrhiza } \\
\text { glabra }\end{array}$ & Fabaceae & - & 53.46 & $\begin{array}{l}\text { SARS-CoV-2 } \\
\text { infected Vero } \\
\text { E6 cells }\end{array}$ & {$[28]$} \\
\hline
\end{tabular}


Table 4 (continued)

\begin{tabular}{|c|c|c|c|c|c|c|c|}
\hline Plant origin & Compound & Plant & Family & $\mathrm{IC}_{50}(\mu \mathrm{M})$ & $\mathrm{EC}_{50}(\mu \mathrm{M})$ & Model & References \\
\hline Asia & Myricetin & Myrica rubra & Myricaceae & 0.22 & - & $\begin{array}{l}\text { In vitro assay } \\
\text { against } \\
\text { SARS-CoV-2 } \\
\text { M }^{\text {pro }} / 3 \mathrm{CL}^{\text {pro }}\end{array}$ & [33] \\
\hline N/D & Osajin & Maclura pomifera & Moraceae & 3.87 & - & $\begin{array}{l}\text { SARS-CoV-2 } \\
\text { infected Vero } \\
\text { cells }\end{array}$ & [47] \\
\hline N/D & Ouabain & $\begin{array}{c}\text { Acokanthera } \\
\text { ouabaio }\end{array}$ & Apocynaceae & 0.024 & - & $\begin{array}{l}\text { SARS-CoV-2 } \\
\text { infected Vero } \\
\text { E6 cells }\end{array}$ & [48] \\
\hline \multirow[t]{4}{*}{ Thailand } & Panduratin A & $\begin{array}{l}\text { Boesenbergia } \\
\text { rotunda }\end{array}$ & Zingiberaceae & 0.81 & - & $\begin{array}{l}\text { SARS-CoV-2 } \\
\text { infected Vero } \\
\text { E6 cells by IFA } \\
\text { assay }\end{array}$ & [26] \\
\hline & & & & 2.04 & - & $\begin{array}{l}\text { SARS-CoV-2 } \\
\text { infected Calu-3 } \\
\text { cells by IFA } \\
\text { assay }\end{array}$ & \\
\hline & & & & 0.53 & - & $\begin{array}{l}\text { SARS-CoV-2 NP } \\
\text { mAb plaque } \\
\text { reduction assay } \\
\text { in Calu- } 3 \text { cells }\end{array}$ & \\
\hline & & & & 0.078 & - & $\begin{array}{l}\text { SARS-CoV-2 NP } \\
\text { mAb plaque } \\
\text { reduction assay } \\
\text { in Vero cells }\end{array}$ & \\
\hline China & Phillyrin & $\begin{array}{l}\text { Forsythia sus- } \\
\quad \text { pensa }\end{array}$ & Oleaceae & 1.13 & - & $\begin{array}{l}\text { SARS-CoV-2 } \\
\text { infected Vero } \\
\text { E6 cells }\end{array}$ & [66] \\
\hline Korea & Platycodin D & $\begin{array}{l}\text { Platycodon gran- } \\
\text { diflorum }\end{array}$ & Campanulaceae & 0.69 & - & $\begin{array}{l}\text { In vitro study } \\
\text { using ACE2 } 2^{+} \\
\text {cells using } \\
\text { H1299 cells }\end{array}$ & [34] \\
\hline N/D & Quercetin & N/D & & 4.48 & - & $\begin{array}{l}\text { Inhibition of } \\
\text { rhACE2 } \\
\text { (recombinant } \\
\text { human) in vitro }\end{array}$ & [33] \\
\hline China & Scutellarein & $\begin{array}{l}\text { Erigeron karvin- } \\
\text { skianus }\end{array}$ & Compositae & 5.80 & - & $\begin{array}{l}\text { SARS-CoV-2 } \\
\text { in vitro }\end{array}$ & {$[1]$} \\
\hline Asia & Tetandrine & $\begin{array}{l}\text { Stephania tetran- } \\
\quad \text { dra }\end{array}$ & Menispermaceae & 3 & - & $\begin{array}{l}\text { SARS-CoV-2 } \\
\text { infected Vero } \\
\text { cells }\end{array}$ & [47] \\
\hline Korea & $\begin{array}{l}\text { Tetrahydrocan- } \\
\text { nabinol }\end{array}$ & Cannabis sativa & Cannabaceae & 10.25 & - & $\begin{array}{l}\text { SARS-CoV-2 } \\
\text { infected Vero } \\
\text { cells }\end{array}$ & {$[65]$} \\
\hline Asia & Theaflavin & Camellia sinensis & Theaceae & 14.95 & - & $\begin{array}{l}\text { In vitro assay } \\
\text { against } \\
\text { SARS-CoV-2 } \\
\text { M }^{\text {pro }} / 3 \mathrm{CL}^{\text {pro }}\end{array}$ & {$[35]$} \\
\hline Asia & Allicin & Allium sativum & Amaryllidaceae & - & - & $\begin{array}{l}\text { Sub-lethal effect } \\
\text { at } 50-75 \mu \mathrm{M} \\
\text { with SARS- } \\
\text { CoV-2 infected } \\
\text { Vero E6 cell }\end{array}$ & {$[67]$} \\
\hline N/D & Betulinic acid & Olea europaea & Oleaceae & 10 & - & $\begin{array}{l}\text { In vitro assay } \\
\text { against } \\
\text { SARS-CoV-2 } \\
\mathrm{M}^{\text {pro }} / 3 \mathrm{CL}^{\text {pro }}\end{array}$ & {$[68]$} \\
\hline
\end{tabular}


Table 4 (continued)

\begin{tabular}{|c|c|c|c|c|c|c|c|}
\hline Plant origin & Compound & Plant & Family & $\mathrm{IC}_{50}(\mu \mathrm{M})$ & $\mathrm{EC}_{50}(\mu \mathrm{M})$ & Model & References \\
\hline N/D & Betulin & Olea europaea & Oleaceae & 89.67 & - & $\begin{array}{l}\text { In vitro assay } \\
\text { against } \\
\text { SARS-CoV-2 } \\
\mathrm{M}^{\text {pro }} / 3 \mathrm{CL}^{\text {pro }}\end{array}$ & {$[68]$} \\
\hline N/D & Ursolic acid & Olea europaea & Oleaceae & 12.57 & - & $\begin{array}{l}\text { In vitro assay } \\
\text { against } \\
\text { SARS-CoV-2 } \\
\text { M }^{\text {pro }} 3 \mathrm{CL}^{\text {pro }}\end{array}$ & {$[68]$} \\
\hline N/D & Maslinic acid & Olea europaea & Oleaceae & 3.22 & - & $\begin{array}{l}\text { In vitro assay } \\
\text { against } \\
\text { SARS-CoV-2 } \\
\mathrm{M}^{\text {pro }} / 3 \mathrm{CL}^{\text {pro }}\end{array}$ & {$[68]$} \\
\hline Egypt & Cnicin & Cnicus benedictus & Compositae & 3.12 & - & $\begin{array}{l}\text { SARS-CoV-2 } \\
\text { infected Vero } \\
\text { E6 cells }\end{array}$ & [69] \\
\hline Egypt & Arctiin & Cnicus benedictus & Compositae & $>150$ & - & $\begin{array}{l}\text { SARS-CoV-2 } \\
\text { infected Vero } \\
\text { E6 cells }\end{array}$ & [69] \\
\hline Egypt & Sitogluside & Cnicus benedictus & Compositae & $>150$ & - & $\begin{array}{l}\text { SARS-CoV-2 } \\
\text { infected Vero } \\
\text { E6 cells }\end{array}$ & [69] \\
\hline Egypt & Nortracheloside & Cnicus benedictus & Compositae & $>150$ & - & $\begin{array}{l}\text { SARS-CoV-2 } \\
\text { infected Vero } \\
\text { E6 cells }\end{array}$ & [69] \\
\hline Egypt & $\begin{array}{l}\text { Apigenin 7-O-glu- } \\
\text { coside }\end{array}$ & Cnicus benedictus & Compositae & $>200$ & - & $\begin{array}{l}\text { SARS-CoV-2 } \\
\text { infected Vero } \\
\text { E6 cells }\end{array}$ & [69] \\
\hline Egypt & Luteolin & Cnicus benedictus & Compositae & $>300$ & - & $\begin{array}{l}\text { SARS-CoV-2 } \\
\text { infected Vero } \\
\text { E6 cells }\end{array}$ & [69] \\
\hline Egypt & Astragalin & Cnicus benedictus & Compositae & $>200$ & - & $\begin{array}{l}\text { SARS-CoV-2 } \\
\text { infected Vero } \\
\text { E6 cells }\end{array}$ & [69] \\
\hline China & Vanicoside A & $\begin{array}{l}\text { Reynoutria sacha- } \\
\quad \text { linensis }\end{array}$ & Polygonaceae & 1.364 & - & $\begin{array}{l}\text { In vitro assay } \\
\text { against } \\
\text { SARS-CoV-2 } \\
\mathrm{M}^{\text {pro }} / 3 \mathrm{CL}^{\text {pro }}\end{array}$ & {$[62]$} \\
\hline China & Vanicoside B & $\begin{array}{l}\text { Reynoutria sacha- } \\
\text { linensis }\end{array}$ & Polygonaceae & 1.639 & - & $\begin{array}{l}\text { In vitro assay } \\
\text { against } \\
\text { SARS-CoV-2 } \\
\mathrm{M}^{\text {pro }} / 3 \mathrm{CL}^{\text {pro }}\end{array}$ & {$[62]$} \\
\hline China & Kobophenol A & Caragana sinica & Leguminosae & - & 71.6 & $\begin{array}{l}\text { SARS-CoV-2 } \\
\text { infected Vero } \\
\text { E6 cells }\end{array}$ & {$[70]$} \\
\hline China & Dihydromyricetin & $\begin{array}{l}\text { Ampelopsis gros- } \\
\text { sedentata }\end{array}$ & Vitaceae & 4.91 & - & $\begin{array}{l}\text { In vitro assay } \\
\text { against } \\
\text { SARS-CoV-2 } \\
\mathrm{M}^{\text {pro }} 3 \mathrm{CL}^{\text {pro }}\end{array}$ & [71] \\
\hline China & $\begin{array}{l}\text { Isodihydromyri- } \\
\text { cetin }\end{array}$ & $\begin{array}{l}\text { Ampelopsis gros- } \\
\text { sedentata }\end{array}$ & Vitaceae & 3.73 & - & $\begin{array}{l}\text { In vitro assay } \\
\text { against } \\
\text { SARS-CoV-2 } \\
\mathrm{M}^{\text {pro }} / 3 \mathrm{CL}^{\text {pro }}\end{array}$ & [71] \\
\hline China & Taxifolin & $\begin{array}{l}\text { Ampelopsis gros- } \\
\text { sedentata }\end{array}$ & Vitaceae & 72.27 & - & $\begin{array}{l}\text { In vitro assay } \\
\text { against } \\
\text { SARS-CoV-2 } \\
\mathrm{M}^{\text {pro }} / 3 \mathrm{CL}^{\text {pro }}\end{array}$ & [71] \\
\hline
\end{tabular}


Table 4 (continued)

\begin{tabular}{|c|c|c|c|c|c|c|c|}
\hline Plant origin & Compound & Plant & Family & $\mathrm{IC}_{50}(\mu \mathrm{M})$ & $\mathrm{EC}_{50}(\mu \mathrm{M})$ & Model & References \\
\hline China & Ebselen & $\begin{array}{l}\text { Ampelopsis gros- } \\
\text { sedentata }\end{array}$ & Vitaceae & 2.62 & - & $\begin{array}{l}\text { In vitro assay } \\
\text { against } \\
\text { SARS-CoV-2 } \\
\mathrm{M}^{\text {pro }} / 3 \mathrm{CL}^{\text {pro }}\end{array}$ & [71] \\
\hline China & Resveratrol & N/D & N/D & - & 4.48 & $\begin{array}{l}\text { SARS-CoV-2 } \\
\text { infected Vero } \\
\text { cells }\end{array}$ & [72] \\
\hline N/D & Hopeaphenol & N/D & N/D & 42.5 & - & $\begin{array}{l}\text { In vitro assay } \\
\text { against } \\
\text { SARS-CoV-2 } \\
\mathrm{M}^{\text {pro }} / 3 \mathrm{CL}^{\text {pro }}\end{array}$ & [73] \\
\hline N/D & Vaticanol B & $\mathrm{N} / \mathrm{D}$ & N/D & 47.6 & - & $\begin{array}{l}\text { In vitro assay } \\
\text { against } \\
\text { SARS-CoV-2 } \\
\mathrm{M}^{\text {pro }} / 3 \mathrm{CL}^{\text {pro }}\end{array}$ & [73] \\
\hline
\end{tabular}

Dengue virus [42]. The study showed that the antiviral activity against SARS-CoV-2 was superior to the FDAapproved drug, hydroxychloroquine. The value of cytotoxicity against the normal Vero E6 cell line was $14.71 \mu \mathrm{M}$ [26]. However, molecular targets for this compound have not been well explored.

Baicalin and baicalein, active compounds isolated from Scutellaria baicalensis, are used in TCM for treatment of respiratory disorders, heat clearing, detoxification, fire purging, and viral diseases, including hepatitis. The herb has shown antitumor, antimicrobial, anti-inflammatory, and broad-spectrum antiviral activity against various viruses, such as Zika, HIV, DENV, and H1N1. Baicalin and baicalein have shown inhibitory activity against the $3 \mathrm{CL}^{\text {pro }}$ main protease of SARS-CoV-2, with $\mathrm{IC}_{50}$ values of $6.41 \mu \mathrm{M}$ and $0.94 \mu \mathrm{M}$, respectively. The anti-SARS-CoV-2 activity of baicalein has been shown to be superior to that of baicalin $[43,44]$. In a cell assay model using SARS-Co-2-infected Vero E6 cells, baicalein exhibited $\mathrm{IC}_{50}$ and $\mathrm{EC}_{50}$ values of 0.39 and $2.94 \mu \mathrm{M}$, respectively. The $\mathrm{CC}_{50}$ of baicalein against Vero E6 cells was $>200 \mu \mathrm{M}$, which is categorized as low cytotoxicity. Baicalein reportedly has closed activity with chloroquine, with an $\mathrm{EC}_{50}$ of $2.71 \mu \mathrm{M}$ [43, 45]. This compound reportedly inhibited viral replication by blocking $3 \mathrm{CL}^{\text {pro }}$ via in an in vitro study, and a molecular docking study showed that the 6-OH and 7-OH of its structure interacted with a carbonyl group of Leu141 and an amide group of Gly143 of 3CL ${ }^{\text {pro }}$, respectively [43]. In addition, baicalein also has been reported to inhibit the RdRp SARS-CoV-2 in an in vitro assay. In the subsequent molecular docking study, inhibition was not predicted on the active site of the enzyme since it is not an analog of a nucleoside. An in silico study showed that the compound had binding affinities with the Asn705 and His133 residues of RdRp on the palm subdomain and nucleotidyltransferase, respectively [46].
Furthermore, cardiac glycosides, including digoxin, digitoxin, and ouabain, also have shown good properties for treating COVID-19 disease. Cardiac glycosides, molecules that contain a steroid moiety, a 5-6C lactone ring, and a sugar moiety, have been suggested as promising treatments for COVID-19 by targeting NA ${ }^{+} / \mathrm{K}^{+}$-ATPase (NKA). Some cardiac glycosides have shown antiviral activity through inhibition of NKA and activation of tyrosine kinase (Src). Src regulates nuclear factor kappa B (NFkB), which is the important transcription factor for SARS-CoV-2 [36].

Digoxin and digitoxin, FDA-approved drugs for cardiovascular diseases, are isolated from Digitalis purpurea and reported to have activity against SARS-CoV-2-infected Vero cells based on their cytopathic effect, with $\mathrm{IC}_{50}$ values of $0.19 \mu \mathrm{M}$ and $0.23 \mu \mathrm{M}$, respectively. The evaluation of cytotoxicity is measured at a $\mathrm{CC}_{50}>50 \mu \mathrm{M}$ for both compounds [47]. Another report with a different assay showed inhibitory activity of digoxin against SARS-CoV-2-infected Vero cells (human isolate BetaCoV/Korea), with an $\mathrm{IC}_{50}$ of $0.043 \mu \mathrm{M}$ and a $\mathrm{CC}_{50}>10 \mu \mathrm{M}$. The $\mathrm{IC}_{50}$ of digoxin has been shown to be tenfold higher than those of chloroquine and remdesivir, which have $\mathrm{IC}_{50}$ values of $0.526 \mu \mathrm{M}$ and $1.57 \mu \mathrm{M}$, respectively. Digoxin also inhibited viral mRNA expression, protein expression, and viral copy number. Furthermore, the inhibition of mRNA expression of digoxin was superior to those of remdesivir and chloroquine. However, digoxin reportedly is not effective in the viral entry stage. Digoxin appears to act as a viral RNA synthesis inhibitor [48]. On the other hand, digitoxin can suppress the levels of cytokines, including TNF $\alpha, \mathrm{M} 1 \mathrm{P} 2, \mathrm{IFN} \gamma, \mathrm{MCP} 1$, and $\mathrm{GRO} / \mathrm{KC}$ in an influenza-infected rat lung model. This finding implied that digitoxin may be able to block the cytokine storm caused by the elevated levels of pro-inflammatory cytokines during coronavirus infection. Digitoxin was reported as one of the top-ten pro-inflammatory cytokine inhibitors among 2800 

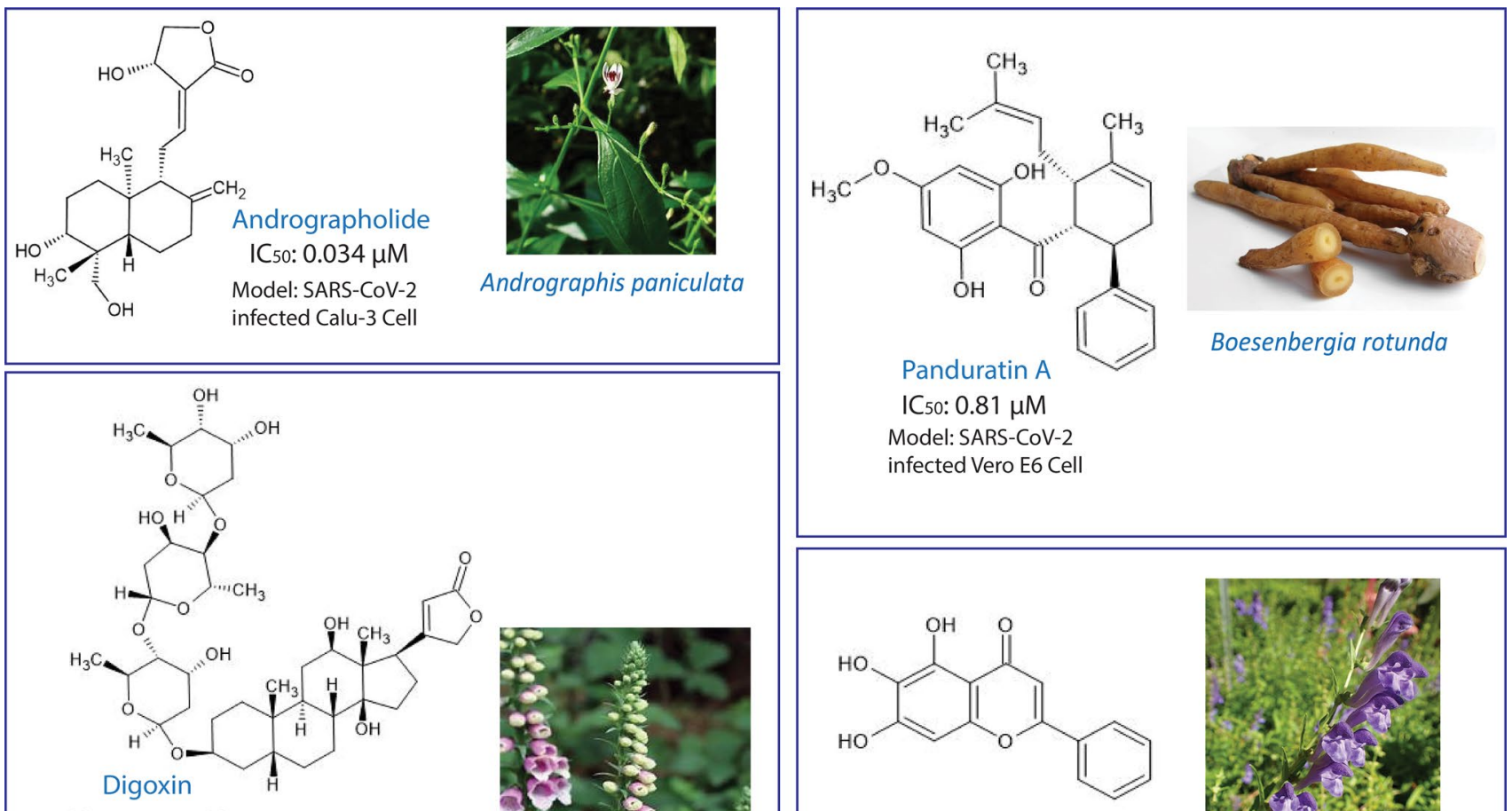

IC $50: 0.043 \mu \mathrm{M}$

Model: SARS-CoV-2

infected Vero Cell

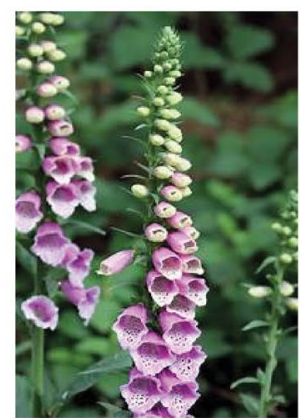<smiles>O=c1cc(-c2ccccc2)oc2cc(O)c(O)c(O)c12</smiles>

Baicalein

IC $50: 0.39 \mu \mathrm{M}$

Model: SARS-CoV-2 infected Vero Cell

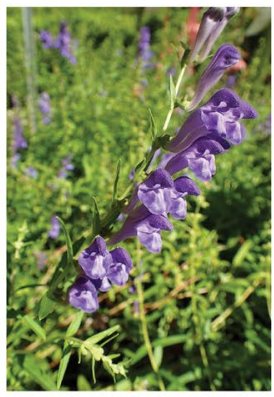

Scutellaria baicalensis

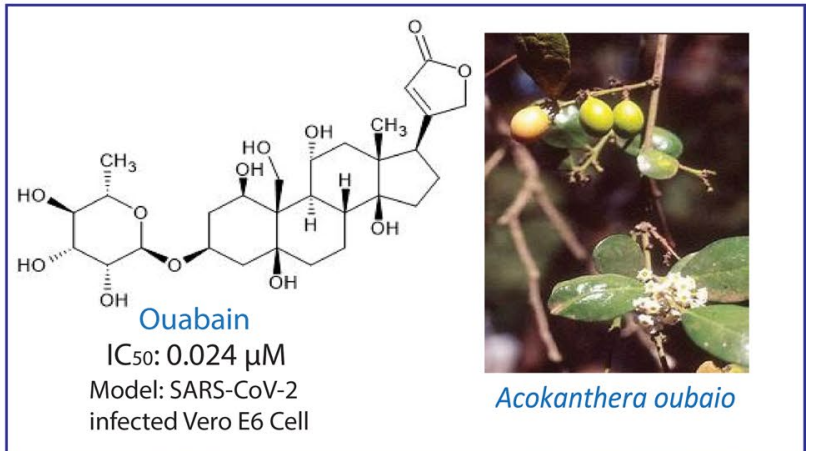

Fig. 4 Promising natural product isolated from medicinal plants as an antiviral drug against SARS-CoV-2 in a cell model

FDA-approved drugs by suppressing TNF $\alpha$-activated NFkB. Furthermore, compared with digoxin, digitoxin has an affinity to the SARS-CoV-2 spike pseudo-typed VSV in human lung cells and hence is able to block ACE2-S binding for viral entry. Digoxin is postulated to act as an inhibitor at the intracellular level of the host cell rather than at the entry stage $[49,50]$.

On the other hand, ouabain reportedly showed the antiviral activity against SARS-CoV-2-infected Vero cells, with an $\mathrm{IC}_{50}$ of $0.024 \mu \mathrm{M}$ and a $\mathrm{CC}_{50}>416.66 \mu \mathrm{M}$. The $\mathrm{IC}_{50}$ of ouabain is reported to be superior to those of chloroquine and remdesivir. This compound also exhibited inhibition of viral copy number, mRNA, and protein expression. It has been postulated that ouabain inhibits at the viral entry stage by blocking Src-mediated endocytosis [48]. Furthermore, another study reported that the blocking ability of ouabain occurred via binding to the S protein of SARS-CoV-2, so it also may block viral penetration into human lung cells [50].

\section{Conclusion}

Herbal medicine has been applied in the treatment of COVID-19 disease in various Asian cultures. Several medicinal plants from both single- and multiple-component herbal medicines have been found to have antiviral 


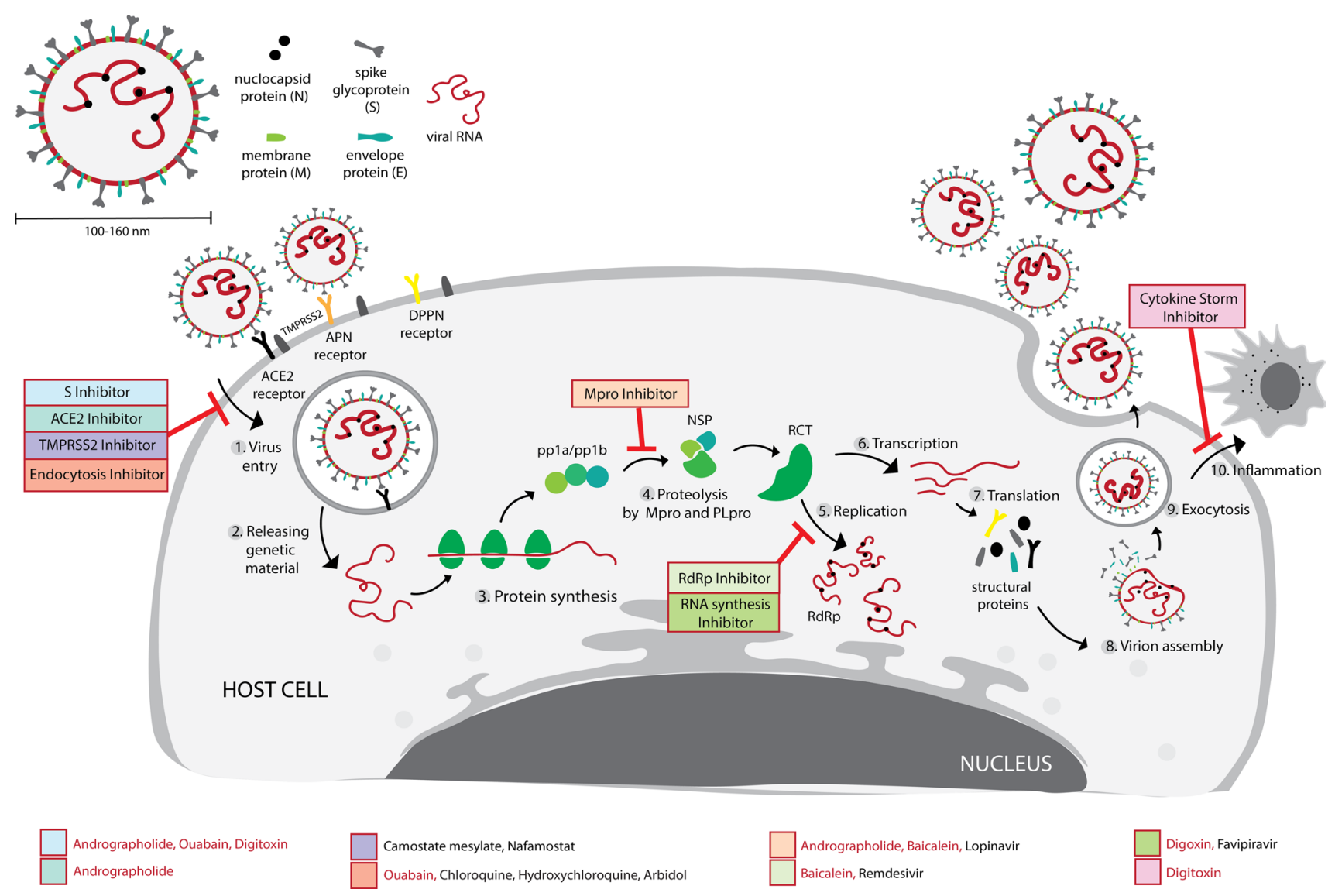

Fig. 5 Summary of the antiviral activity in cell targets of selected isolated active compounds from medicinal plants (highlighted in red) and FDA-approved drugs/antiviral agents against SARS-CoV-2 (highlighted in black)

properties against SARS-CoV-2 in cell-based assays and in vitro studies against various molecular targets, which implies some degree of efficacy for these traditional medicines. Our review showed that the Lamiaceae family was the most frequently used plant family in the treatment and prevention of COVID-19, which suggests that it is a promising source of antiviral agents. In addition, a direct approach using testing of isolated compounds from medicinal plants against SARS-CoV-2 also revealed some promising antiviral activity when compared with repurposed FDA-approved drugs (e.g., digoxin, digitoxin, panduratin $\mathrm{A}$, and andrographolide). These Lamiaceae family members and the isolated compounds discussed in the review warrant further investigations for their activities against coronaviruses, including SAR-CoV-2.

Acknowledgements We would like to thank the College of Public Health Science, Chulalongkorn University.

Author contributions AP and DL designed the study. AP initiated the concept and idea, supervised it, provided input, and revised the manuscript. DL collected, curated, analyzed the data, and wrote the draft of the manuscript. All authors made equal contributions, have read the manuscript, and agreed on the final form for submission.

Funding No funding was received to assist with the preparation of this manuscript.

Availability of data and materials All data are obtained from published literatures which are presented in the references.

\section{Declarations}

Conflict of interest Authors declared there is no competing of interest.

Ethic approval and consent to participate Not applicable.

\section{References}

1. Wang Z, Yang L (2021) Chinese herbal medicine: fighting SARSCoV-2 infection on all fronts. J Ethnopharmacol 270:113869. https://doi.org/10.1016/j.jep.2021.113869

2. Illian DN, Siregar ES, Sumaiyah S, Utomo AR, Nuryawan A, Basyuni M (2021) Potential compounds from several Indonesian 
plants to prevent SARS-CoV-2 infection: a mini-review of SARS-CoV-2 therapeutic targets. Heliyon 7(1):e06001. https:// doi.org/10.1016/j.heliyon.2021.e06001

3. Teuwen L-A, Geldhof V, Pasut A, Carmeliet P (2020) COVID19: the vasculature unleashed. Nat Rev Immunol 20(7):389391. https://doi.org/10.1038/s41577-020-0343-0

4. Leung EL-H, Pan H-D, Huang Y-F, Fan X-X, Wang W-Y, He F, Cai J, Zhou H, Liu L (2020) The scientific foundation of Chinese herbal medicine against COVID-19. Engineering 6(10):1099-1107. https://doi.org/10.1016/j.eng.2020.08.009

5. Akindele AJ, Agunbiade FO, Sofidiya MO, Awodele O, Sowemimo A, Ade-Ademilua O, Akinleye MO, Ishola IO, Orabueze I (2020) COVID-19 Pandemic: a case for phytomedicines. Nat Prod Commun 15(8):1-9. https://doi.org/10.1177/1934578X20 945086

6. Codagenix I (2019) Codagenix and Serum Institute of India Initiate Co-Development of a Scalable, Live-Attenuated Vaccine Against the 2019 Novel Coronavirus, COVID-19. https://www. prnewswire.com/news-releases/codagenix-and-serum-institute-ofindia-initiate-co-development-of-a-scalable-live-attenuated-vacci ne-against-the-2019-novel-coronavirus-covid-19-301004654. html. Accessed 25 July 2021

7. Wu Z, Hu Y, Xu M, Chen Z, Yang W, Jiang Z, Li M, Jin H, Cui G, Chen P (2021) Safety, tolerability, and immunogenicity of an inactivated SARS-CoV-2 vaccine (CoronaVac) in healthy adults aged 60 years and older: a randomised, double-blind, placebo-controlled, phase 1/2 clinical trial. Lancet Infect Dis 21(6):803-812. https://doi.org/10.1016/S1473-3099(20)30987-7

8. Baraniuk C (2021) What do we know about China's covid-19 vaccines? BMJ 373:n912. https://doi.org/10.1136/bmj.n912

9. Britton A, Slifka KMJ, Edens C, Nanduri SA, Bart SM, Shang N, Harizaj A, Armstrong J, Xu K, Ehrlich HY (2021) Effectiveness of the Pfizer-BioNTech COVID-19 vaccine among residents of two skilled nursing facilities experiencing COVID-19 outbreaks-Connecticut, December 2020-February 2021. MMWR Morb Mortal Wkly Rep 70(11):396-401

10. Oliver SE (2020) The advisory committee on immunization practices' interim recommendation for use of moderna COVID-19 vaccine-United States, December 2020. MMWR Morb Mortal Wkly Rep 69:1653-1656

11. ClinicalTrials.gov. ChulaCov19 mRNA vaccine in healthy adults. https://clinicaltrials.gov/ct2/show/NCT04566276. Accessed 25 July 2021

12. Cohen J. What went wrong with CureVac's mRNA vaccine? Accessed 20 July 2021

13. ClinicalTrials.gov. The safety and immunogenicity of a DNAbased Vaccine (COVIGEN) in Healthy Volunteers (COVALIA). https://clinicaltrials.gov/ct2/show/NCT04742842. Accessed 25 July 2021

14. ClinicalTrials.gov. Safety, tolerability and immunogenicity of INO-4800 followed by electroporation in healthy volunteers for COVID19. https://clinicaltrials.gov/ct2/show/NCT04447781. Accessed 25 July 2021

15. Knoll MD, Wonodi C (2021) Oxford-AstraZeneca COVID-19 vaccine efficacy. Lancet Inf Dis 397(10269):72-74. https://doi. org/10.1016/S0140-6736(20)32623-4

16. Livingston EH, Malani PN, Creech CB (2021) The Johnson \& Johnson Vaccine for COVID-19. JAMA 325(15):1575-1575. https://doi.org/10.1001/jama.2021.2927

17. Mahase E (2021) Covid-19: Novavax vaccine efficacy is $86 \%$ against UK variant and 60\% against South African variant. BMJ 372:n296. https://doi.org/10.1136/bmj.n296

18. Li Y, Tenchov R, Smoot J, Liu C, Watkins S, Zhou Q (2021) A comprehensive review of the global efforts on COVID-19 vaccine development. ACS Cent Sci 7(4):512-533. https://doi.org/ 10.1021/acscentsci. $1 \mathrm{c} 00120$
19. WHO. Coronavirus disease (COVID-19): vaccines. https://www. who.int/news-room/q-a-detail/coronavirus-disease-(covid-19)vaccines?adgroupsurvey. Accessed 11 July 2021

20. Zhao J, Zhao S, Ou J, Zhang J, Lan W, Guan W, Wu X, Yan Y, Zhao W, Wu J (2020) COVID-19: vaccine development updates. Front Immunol 11:3435. https://doi.org/10.3389/fimmu.2020. 602256

21. Cragg GM, Newman DJ (2001) Natural product drug discovery in the next millennium. Pharm Biol 39(sup1):8-17. https://doi.org/ 10.1076/phbi.39.s1.8.0009

22. Patwardhan B, Mashelkar RA (2009) Traditional medicineinspired approaches to drug discovery: can Ayurveda show the way forward? Drug Discov Today 14(15):804-811. https://doi. org/10.1016/j.drudis.2009.05.009

23. Sucher NJ (2013) The application of Chinese medicine to novel drug discovery. Expert Opin Drug Disc 8(1):21-34. https://doi. org/10.1517/17460441.2013.739602

24. Shahrajabian MH, Sun W, Cheng Q (2020) Traditional herbal medicine for the prevention and treatment of cold and flu in the autumn of 2020, overlapped with COVID-19. Nat Prod Commun 15(8):1-10. https://doi.org/10.1177/1934578X20951431

25. Shahrajabian MH, Sun W, Shen H, Cheng Q (2020) Chinese herbal medicine for SARS and SARS-CoV-2 treatment and prevention, encouraging using herbal medicine for COVID-19 outbreak. Acta Agric Scand Soil Plant Sci 70(5):437-443. https://doi. org/10.1080/09064710.2020.1763448

26. Kanjanasirirat P, Suksatu A, Manopwisedjaroen S, Munyoo B, Tuchinda P, Jearawuttanakul K, Seemakhan S, Charoensutthivarakul S, Wongtrakoongate P, Rangkasenee N (2020) Highcontent screening of Thai medicinal plants reveals Boesenbergia rotunda extract and its component Panduratin A as anti-SARSCoV-2 agents. Sci Rep 10(1):1-12. https://doi.org/10.1038/ s41598-020-77003-3

27. Shahzad F, Anderson D, Najafzadeh M (2020) The antiviral, antiinflammatory effects of natural medicinal herbs and mushrooms and SARS-CoV-2 infection. Nutrients 12(9):2573. https://doi.org/ 10.3390/nu12092573

28. van de Sand L, Bormann M, Alt M, Schipper L, Heilingloh CS, Steinmann E, Todt D, Dittmer U, Elsner C, Witzke O (2021) Glycyrrhizin effectively inhibits SARS-CoV-2 replication by inhibiting the viral main protease. Viruses 13(4):609. https://doi.org/10. 3390/v13040609

29. Chen H, Du Q (2020) Potential natural compounds for preventing SARS-CoV-2 (2019-nCoV) infection. Preprints. https://doi.org/ 10.20944/preprints202001.0358.v3

30. Asai A, Konno M, Ozaki M, Otsuka C, Vecchione A, Arai T, Kitagawa T, Ofusa K, Yabumoto M, Hirotsu T (2020) COVID-19 drug discovery using intensive approaches. Int J Mol Sci 21(8):2839. https://doi.org/10.3390/ijms21082839

31. Jeong GU, Song H, Yoon GY, Kim D, Kwon Y-C (2020) Therapeutic strategies against COVID-19 and structural characterization of SARS-CoV-2: a review. Front Microbiol 11:1723. https://doi. org/10.3389/fmicb.2020.01723

32. Fernandez-Fernandez B, D'marco L, Górriz JL, Jacobs-Cachá C, Kanbay M, Luis-Lima S, Porrini E, Sarafidis P, Soler MJ, Ortiz A (2020) Exploring sodium glucose co-transporter-2 (SGLT2) inhibitors for organ protection in COVID-19. J Clin Med 9(7):2030. https://doi.org/10.3390/jcm9072030

33. Liu X, Raghuvanshi R, Ceylan FD, Bolling BW (2020) Quercetin and its metabolites inhibit recombinant human angiotensin-converting enzyme 2 (ACE2) activity. J Agric Food Chem 68(47):13982-13989. https://doi.org/10.1021/acs.jafc.0c05064

34. Kim TY, Jeon S, Jang Y, Gotina L, Won J, Ju YH, Kim S, Jang MW, Won W, Park MG, Pae AN, Han S, Kim S, Lee CJ (2021) Platycodin D, a natural component of Platycodon grandiflorum, prevents both lysosome- and TMPRSS2-driven SARS-CoV-2 
infection by hindering membrane fusion. Exp Mol Med 53(5):956-972. https://doi.org/10.1038/s12276-021-00624-9

35. Jang M, Park YI, Cha YE, Park R, Namkoong S, Lee JI, Park J (2020) Tea polyphenols EGCG and theaflavin inhibit the activity of SARS-CoV-2 3CL-protease in vitro. Evid Based Complement Altern Med. https://doi.org/10.1155/2020/5630838

36. Souza KFC, Souza BPTM, de Palmer Paixão ICN, Burth P, Silva AR, Gonçalves-de-Albuquerque CF (2021) Na+/K+-ATPase as a target of cardiac glycosides for the treatment of SARS-CoV-2 infection. Front Pharmacol 12:624704. https://doi.org/10.3389/ fphar.2021.624704

37. Sa-Ngiamsuntorn K, Suksatu A, Pewkliang Y, Thongsri P, Kanjanasirirat P, Manopwisedjaroen S, Charoensutthivarakul S, Wongtrakoongate P, Pitiporn S, Chaopreecha J (2021) AntiSARS-CoV-2 activity of Andrographis paniculata extract and its major component Andrographolide in human lung epithelial cells and cytotoxicity evaluation in major organ cell representatives. $\mathbf{J}$ Nat Prod 84(4):1261-1270. https://doi.org/10.1021/acs.jnatprod. 0c01324

38. Gupta S, Mishra KP, Ganju L (2017) Broad-spectrum antiviral properties of andrographolide. Arch Virol 162(3):611-623. https://doi.org/10.1007/s00705-016-3166-3

39. Maurya VK, Kumar S, Prasad AK, Bhatt MLB, Saxena SK (2020) Structure-based drug designing for potential antiviral activity of selected natural products from Ayurveda against SARS-CoV-2 spike glycoprotein and its cellular receptor. Virus Dis 31(2):179193. https://doi.org/10.1007/s13337-020-00598-8

40. Shi T-H, Huang Y-L, Chen C-C, Pi W-C, Hsu Y-L, Lo L-C, Chen W-Y, Fu S-L, Lin C-H (2020) Andrographolide and its fluorescent derivative inhibit the main proteases of 2019-nCoV and SARS$\mathrm{CoV}$ through covalent linkage. Biochem Biophys Res Commun 533(3):467-473. https://doi.org/10.1016/j.bbrc.2020.08.086

41. Cheenpracha S, Karalai C, Ponglimanont C, Subhadhirasakul S, Tewtrakul S (2006) Anti-HIV-1 protease activity of compounds from Boesenbergia pandurata. Bioorg Med Chem 14(6):17101714. https://doi.org/10.1016/j.bmc.2005.10.019

42. Kiat TS, Pippen R, Yusof R, Ibrahim H, Khalid N, Rahman NA (2006) Inhibitory activity of cyclohexenyl chalcone derivatives and flavonoids of fingerroot, Boesenbergia rotunda (L.), towards dengue-2 virus NS3 protease. Bioorg Med Chem Lett 16(12):3337-3340. https://doi.org/10.1016/j.bmcl.2005.12.075

43. Liu H, Ye F, Sun Q, Liang H, Li C, Lu R, Huang B, Tan W, Lai L (2020) Scutellaria baicalensis extract and baicalein inhibit replication of SARS-CoV-2 and its 3C-like protease in vitro. J Enzyme Inhib Med Chem 36(1):497-503. https://doi.org/10.1101/2020.04. 10.035824

44. Su H, Yao S, Zhao W, Li M, Liu J, Shang W, Xie H, Ke C, Gao M, Yu K (2020) Discovery of baicalin and baicalein as novel, natural product inhibitors of SARS-CoV-2 3CL protease in vitro. BioRxiv. https://doi.org/10.1101/2020.04.13.038687

45. Su H-x, Yao S, Zhao W-f, Li M-j, Liu J, Shang W-j, Xie H, Ke C-q, Hu H-c, Gao M-n, Yu K-q, Liu H, Shen J-s, Tang W, Zhang L-k, Xiao G-f, Ni L, Wang D-w, Zuo J-p, Jiang H-l, Bai F, Wu $\mathrm{Y}, \mathrm{Ye} \mathrm{Y}, \mathrm{Xu}$ Y-c (2020) Anti-SARS-CoV-2 activities in vitro of Shuanghuanglian preparations and bioactive ingredients. Acta Pharmacol Sin 41(9):1167-1177. https://doi.org/10.1038/ s41401-020-0483-6

46. Zandi K, Musall K, Oo A, Cao D, Liang B, Hassandarvish P, Lan S, Slack RL, Kirby KA, Bassit L, Amblard F, Kim B, AbuBakar S, Sarafianos SG, Schinazi RF (2021) Baicalein and baicalin inhibit SARS-CoV-2 RNA-dependent-RNA polymerase. Microorganisms 9(5):893. https://doi.org/10.3390/microorganisms9050893

47. Jeon S, Ko M, Lee J, Choi I, Byun Soo Y, Park S, Shum D, Kim S (2020) Identification of antiviral drug candidates against SARSCoV-2 from FDA-approved drugs. Antimicrob Agents Chemother 64(7):e00819-00820. https://doi.org/10.1128/AAC.00819-20
48. Cho J, Lee YJ, Kim JH, Kim Si, Kim SS, Choi B-S, Choi J-H (2020) Antiviral activity of digoxin and ouabain against SARSCoV-2 infection and its implication for COVID-19. Sci Reports 10(1):16200. https://doi.org/10.1038/s41598-020-72879-7

49. Pollard BS, Blanco JC, Pollard JR (2020) Classical drug digitoxin inhibits influenza cytokine storm, with implications for COVID19 therapy. In Vivo 34(6):3723-3730. https://doi.org/10.21873/ invivo. 12221

50. Caohuy H, Eidelman O, Chen T, Yang Q, Bera A, Walton N, Pollard HB (2021) Common cardiac medications potently inhibit ACE2 binding to the SARS-CoV-2 Spike, and block virus penetration into human lung cells. BioRxiv. https://doi.org/10.1101/2021. 06.02.446343

51. Nguyen PH, Tran VD, Pham DT, Dao TNP, Dewey RS (2021) Use of and attitudes towards herbal medicine during the COVID-19 pandemic: a cross-sectional study in Vietnam. Euro J Integr Med 44:101328. https://doi.org/10.1016/j.eujim.2021.101328

52. Luo H, Tang Q-L, Shang Y-X, Liang S-B, Yang M, Robinson N, Liu J-P (2020) Can Chinese medicine be used for prevention of corona virus disease 2019 (COVID-19)? A review of historical classics, research evidence and current prevention programs. Chin J Integr Med 26(4):243-250. https://doi.org/10.1007/ s11655-020-3192-6

53. Azam MNK, Al Mahamud R, Hasan A, Jahan R, Rahmatullah M (2020) Some home remedies used for treatment of COVID-19 in Bangladesh. J Med Plant Stud 8(4):27-32

54. MOA. Guidelines for Ayuverda Practitioners for COVID19. https://www.ayush.gov.in/docs/ayurved-guidlines.pdf. Accessed 28 May 2021

55. Panyod S, Ho C-T, Sheen L-Y (2020) Dietary therapy and herbal medicine for COVID-19 prevention: a review and perspective. J Tradit Complement Med 10(4):420-427. https://doi.org/10.1016/j. jtcme.2020.05.004

56. Runfeng L, Yunlong H, Jicheng H, Weiqi P, Qinhai M, Yongxia S, Chufang L, Jin Z, Zhenhua J, Haiming J (2020) Lianhuaqingwen exerts anti-viral and anti-inflammatory activity against novel coronavirus (SARS-CoV-2). Pharmacol Res 156:104761. https:// doi.org/10.1016/j.phrs.2020.104761

57. Deng W, Xu Y, Kong Q, Xue J, Yu P, Liu J, Lv Q, Li F, Wei Q, Bao L (2020) Therapeutic efficacy of pudilan xiaoyan oral liquid (PDL) for COVID-19 in vitro and in vivo. Signal Transduct Target Ther 5(1):66. https://doi.org/10.1038/s41392-020-0176-0

58. Mirzaie A, Halaji M, Dehkordi FS, Ranjbar R, Noorbazargan $\mathrm{H}$ (2020) A narrative literature review on traditional medicine options for treatment of corona virus disease 2019 (COVID-19). Complement Ther Clin Pract 40:101214. https://doi.org/10.1016/j. ctcp.2020.101214

59. Sen B (2020) Potentiality and possibility of medicinal plants on ayurvedic principle in prevention and treatment of COVID-19. J Ayurvedic Herb Med 6(2):100-107

60. Anam E, Swachho RB, Jannat K, Rahmatullah M (2021) Home remedies for COVID-19 treatment in Gazipur district, Bangladesh. J Med Plant 9(1):25-28

61. Upadhyay S, Tripathi PK, Singh M, Raghavendhar S, Bhardwaj M, Patel AK (2020) Evaluation of medicinal herbs as a potential therapeutic option against SARS-CoV-2 targeting its main protease. Phytother Res 34(12):3411-3419. https://doi.org/10.1002/ ptr.6802

62. Nawrot-Hadzik I, Zmudzinski M, Matkowski A, Preissner R, Kęsik-Brodacka M, Hadzik J, Drag M, Abel R (2021) Reynoutria rhizomes as a natural source of SARS-CoV-2 Mpro inhibitorsmolecular docking and in vitro study. Pharmaceuticals 14(8):742. https://doi.org/10.3390/ph14080742

63. Li S-y, Chen C, Zhang H-q, Guo H-y, Wang H, Wang L, Zhang X, Hua S-n, Yu J, Xiao P-g, Li R-s, Tan X (2005) Identification of natural compounds with antiviral activities against 
SARS-associated coronavirus. Antivir Res 67(1):18-23. https:// doi.org/10.1016/j.antiviral.2005.02.007

64. Cao R, Hu H, Li Y, Wang X, Xu M, Liu J, Zhang H, Yan Y, Zhao L, Li W, Zhang T, Xiao D, Guo X, Li Y, Yang J, Hu Z, Wang M, Zhong W (2020) Anti-SARS-CoV-2 potential of artemisinins in vitro. ACS Infect Dis 6(9):2524-2531. https://doi.org/10.1021/ acsinfecdis.0c00522

65. Raj V, Park JG, Cho K-H, Choi P, Kim T, Ham J, Lee J (2021) Assessment of antiviral potencies of cannabinoids against SARS$\mathrm{CoV}-2$ using computational and in vitro approaches. Int $\mathrm{J}$ Biol Macromol 168:474-485. https://doi.org/10.1016/j.ijbiomac.2020. 12.020

66. Ma Q, Li R, Pan W, Huang W, Liu B, Xie Y, Wang Z, Li C, Jiang H, Huang J, Shi Y, Dai J, Zheng K, Li X, Hui M, Fu L, Yang Z (2020) Phillyrin (KD-1) exerts anti-viral and anti-inflammatory activities against novel coronavirus (SARS-CoV-2) and human coronavirus $229 \mathrm{E}$ (HCoV-229E) by suppressing the nuclear factor kappa B (NF-кB) signaling pathway. Phytomedicine 78:153296. https://doi.org/10.1016/j.phymed.2020.153296

67. Mösbauer K, Fritsch VN, Adrian L, Bernhardt J, Gruhlke MCH, Slusarenko AJ, Niemeyer D, Antelmann H (2021) Allicin inhibits SARS-CoV-2 replication and abrogates the antiviral host response in the Calu-3 proteome. bioRxiv. https://doi.org/10.1101/2021.05. 15.444275

68. Alhadrami HA, Sayed AM, Sharif AM, Azhar EI, Rateb ME (2021) Olive-derived triterpenes suppress SARS COV-2 main protease: a promising scaffold for future therapeutics. Molecules 26(9):2654. https://doi.org/10.3390/molecules26092654

69. Alhadrami HA, Sayed AM, Hassan HM, Youssif KA, Gaber Y, Moatasim Y, Kutkat O, Mostafa A, Ali MA, Rateb ME, Abdelmohsen UR, Gamaleldin NM (2021) Cnicin as an anti-SARSCoV-2: an integrated in silico and in vitro approach for the rapid identification of potential COVID-19 therapeutics. Antibiotics 10(5):542. https://doi.org/10.3390/antibiotics 10050542

70. Gangadevi S, Badavath VN, Thakur A, Yin N, De Jonghe S, Acevedo O, Jochmans D, Leyssen P, Wang K, Neyts J, Yujie T, Blum G (2021) Kobophenol A inhibits binding of host ACE2 receptor with spike RBD domain of SARS-CoV-2, a lead compound for blocking COVID-19. J Phys Chem Lett 12(7):1793-1802. https:// doi.org/10.1021/acs.jpclett.0c03119

71. Xiong Y, Zhu G-H, Zhang Y-N, Hu Q, Wang H-N, Yu H-N, Qin X-Y, Guan X-Q, Xiang Y-W, Tang H, Ge G-B (2021) Flavonoids in Ampelopsis grossedentata as covalent inhibitors of SARSCoV-2 3CLpro: inhibition potentials, covalent binding sites and inhibitory mechanisms. Int J Biol Macromol 187:976-987. https:// doi.org/10.1016/j.ijbiomac.2021.07.167

72. Yang M, Wei J, Huang T, Lei L, Shen C, Lai J, Yang M, Liu L, Yang Y, Liu G (2020) Resveratrol inhibits the replication of severe acute respiratory syndrome coronavirus 2 (SARS-CoV-2) in cultured Vero cells. Phytother Res 2020:1-3. https://doi.org/10. 1002/ptr.6916

73. Tietjen I, Cassel J, Register ET, Zhou XY, Messick TE, Keeney F, Lu LD, Beattie KD, Rali T, Ertl HCJ, Salvino JM, Davis RA, Montaner LJ (2021) The natural stilbenoid (-)-hopeaphenol inhibits cellular entry of SARS-CoV-2 USA-WA1/2020, B.1.1.7 and B.1.351 variants. bioRxiv. https://doi.org/10.1101/2021.04.29. 442010

Publisher's Note Springer Nature remains neutral with regard to jurisdictional claims in published maps and institutional affiliations. 